\title{
Evaluation of the Effectiveness of Healthy Me a Nutritional and Exercise Program for African American Adolescents in an Urban School Utilizing the COPE/TEEN Program
}

\author{
Patricia D Setlow \\ West Virginia University
}

Follow this and additional works at: https://researchrepository.wvu.edu/etd

\author{
Recommended Citation \\ Setlow, Patricia D, "Evaluation of the Effectiveness of Healthy Me a Nutritional and Exercise Program for \\ African American Adolescents in an Urban School Utilizing the COPE/TEEN Program" (2013). Graduate \\ Theses, Dissertations, and Problem Reports. 3664. \\ https://researchrepository.wvu.edu/etd/3664
}

This Dissertation is protected by copyright and/or related rights. It has been brought to you by the The Research Repository @ WVU with permission from the rights-holder(s). You are free to use this Dissertation in any way that is permitted by the copyright and related rights legislation that applies to your use. For other uses you must obtain permission from the rights-holder(s) directly, unless additional rights are indicated by a Creative Commons license in the record and/ or on the work itself. This Dissertation has been accepted for inclusion in WVU Graduate Theses, Dissertations, and Problem Reports collection by an authorized administrator of The Research Repository @ WVU. For more information, please contact researchrepository@mail.wvu.edu. 
Evaluation of the Effectiveness of Healthy Me a Nutritional and Exercise Program for African American Adolescents in an Urban School Utilizing the COPE/TEEN Program

\author{
Patricia D Setlow CRNP, FNPBC \\ Doctoral Capstone Project submitted to the \\ School of Nursing \\ at West Virginia University \\ in partial fulfillment of the requirements \\ for the degree of
}

Doctor of Nursing Practice

Susan McCrone, PhD, RN, PMHCNS-BC

Stephanie Frost, PhD

Teresa Ritchie, DNP, APRN, FNP-BC

Department of Nursing

Morgantown, West Virginia

2013

Keywords: obesity, adolescents, African American, nutrition, exercise, educational program 


\section{ABSTRACT \\ Evaluation of the Effectiveness of Healthy Me a Nutritional and Exercise Program for African American Adolescents in an Urban School Utilizing the COPE/TEEN Program}

\section{Patricia D Setlow}

\section{Background}

Obesity, a preventable and reversible condition, increases the risk of type 2 diabetes, hypertension, and hyperlipidemia, while decreasing both life expectancy and quality of life (U.S. Department of Health And Human Services, 2001). The national obesity rate for adolescents ages 12-19 years was $18.1 \%$ in the 2007-2008 period, a significant change from 6.1\% in the early 70's (CDC, 2009). According to Barlow (2007) these figures have sounded alarms for all involved in the health care of children and adolescents.

\section{Objectives}

The purpose of this pilot program was to assess the effectiveness of providing nutritional education and exercise opportunities for African American adolescents in an urban school utilizing the COPE/TEEN program. The primary goals of the Healthy Me project were threefold. The first was to address the presumed deficit in knowledge of what constitute a healthy lifestyle including knowledge of good nutrition and the importance of regular physical exercise and to fill in the gaps that exist in that knowledge. The second goal was to assist overweight and obese adolescents to decrease their weight and BMI through health education and physical exercise. The third goal was the continuation of the emphasis within the school on healthy living for the students. To facilitate this goal, all board members and administrators were provided with the students' baseline health information in aggregate format. Design The study used a one group pretest-posttest quasi experimental design. Instruments used were: Healthy Lifestyle Belief Scale (HLBS), Healthy Lifestyle Choice Scale (HLCS), Nutritional Knowledge (NK), and Youth Adolescent Activity Questionnaire (YAAQ).

Subjects

The subjects were $9^{\text {th }}$ grade students attending St Frances Academy, a small Catholic high school in urban Baltimore whose parents signed consent forms and who signed assent forms.

Results

Despite the large discrepancies between students' weight gain and loss in this project, many students decreased their BMI. Two students reduced their BMI from overweight to normal category and two students from obese to overweight during the course of the program. In addition, one student went from underweight to normal weight. Scales relating to health beliefs and ability to make healthy behavior choices improved from pre to post intervention. $(\mathrm{p}=0.007)$ and $(\mathrm{p}=0.003)$ respectively

Conclusion

Providing a manualized program that educates adolescents about healthy nutrition and needed physical exercise incorporated into the normal school day is an effective strategy in improving healthy lifestyles and in weight management. 


\section{ACKNOWLEDGMENTS}

I would like to acknowledge and thank the following:

My capstone chair, Dr. Susan McCrone and committee members, Dr Stephanie Frost and Dr Teresa Ritchie for their patience, support, expertise and guidance in my mission to progress toward proficiency in addressing adolescent obesity in the urban African American adolescent in clinical practice.

Dr. Marcella Copes, chair Coppin State University Helene Fuld School of Nursing for her inspiration, and mentoring throughout this project and through my academic career.

My daughter Carson and son Cortland for their encouragement, love, and support.

Finally, my husband and partner Michael in this as in all aspects of our life. I appreciate your love, patience, understanding and encouragement, and particularly for your having learned APA! 
Table of Contents

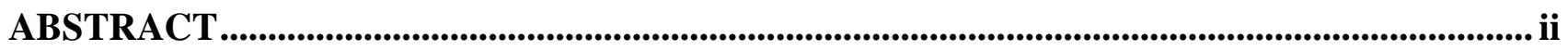

ACKNOWLEDGMENTS ..........................................................................................................

TABLE OF CONTENTS ............................................................................................................ iv

CHAPTER I: INTRODUCTION ................................................................................................................ 1

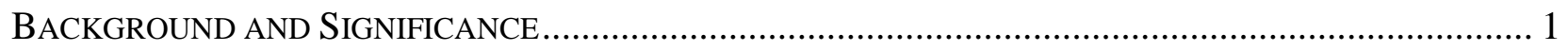

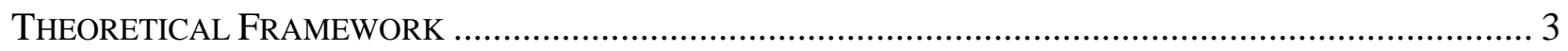

Pender’s Health Promotion Model Theory Literature ReVIEW ............................................. 6

CHAPTER II: LITERATURE REVIEW AND SYNTHESIS .......................................................... 7

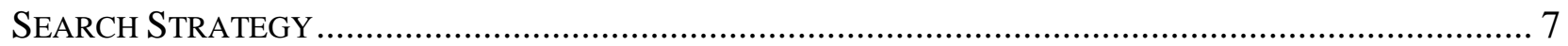

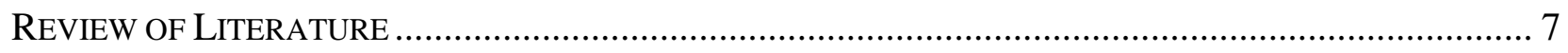

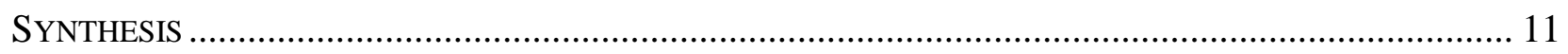

GOALS AND OBJECTIVES .................................................................................................. 13

CHAPTER III: METHODOLOGY ............................................................................................. 14

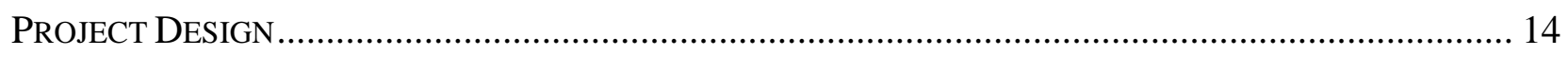

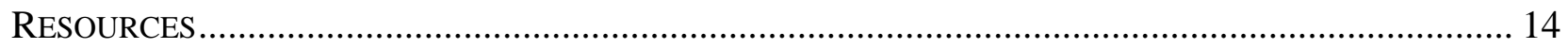

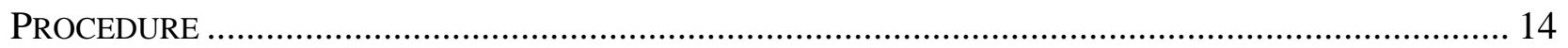

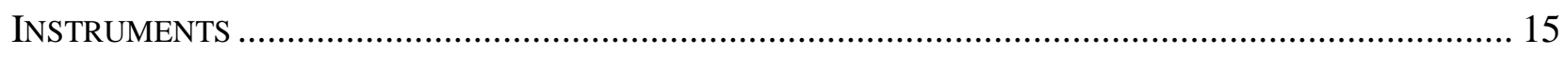

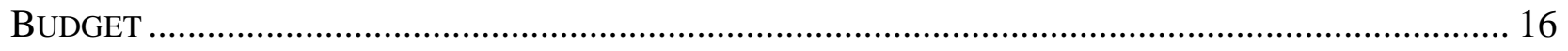

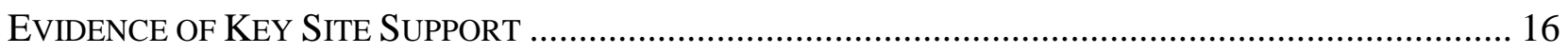

CHAPTER IV: RESULTS ......................................................................................................... 17

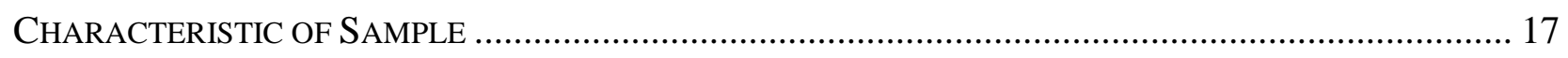

CHAPTER V: DISCUSSION, SUMMARY AND IMPLICATIONS ........................................... 21

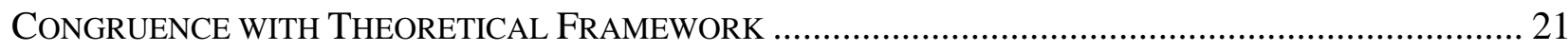

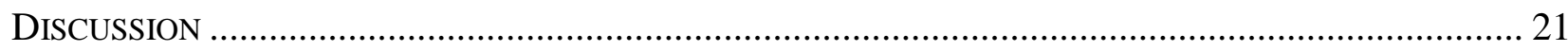

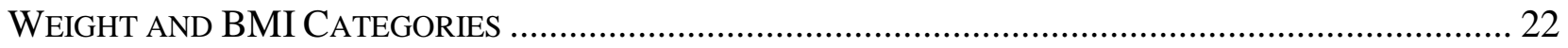

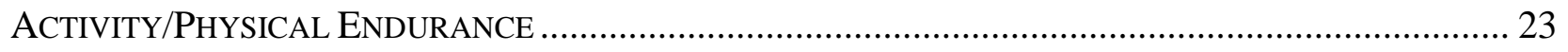

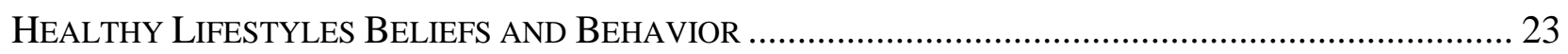




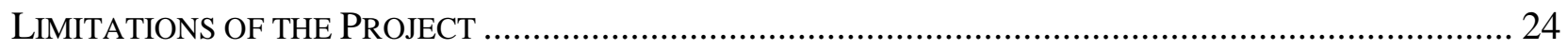

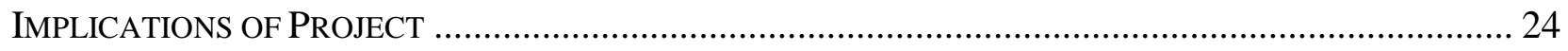

IMPLICATIONS FOR DOCTORATE OF NURSING PRACTICE (DNP) ................................................ 25

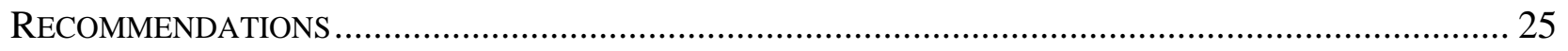

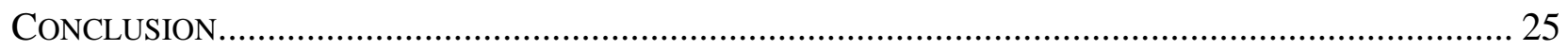

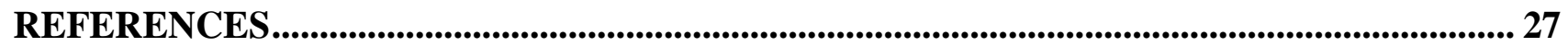

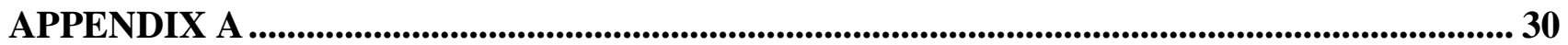

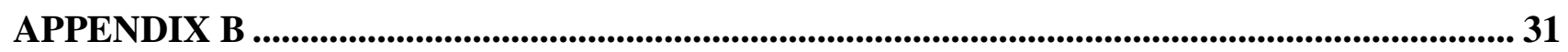

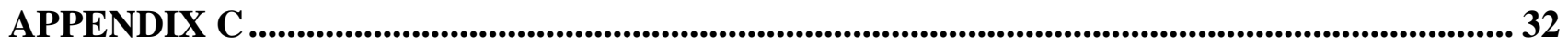

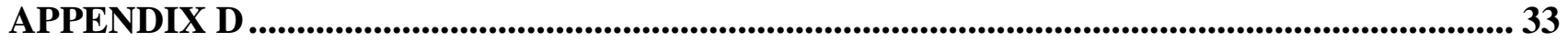

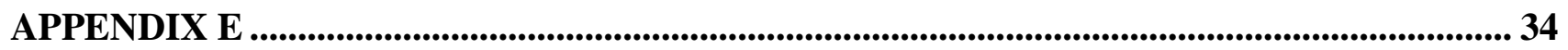

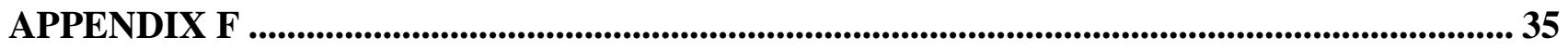

APPENDIX G .................................................................................................................................... 36

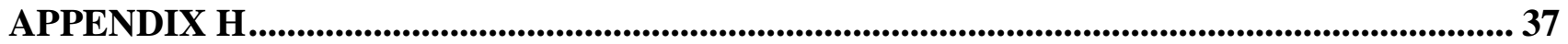

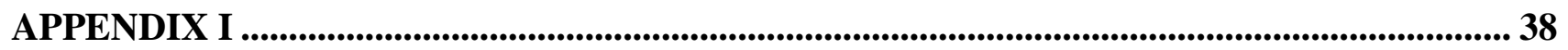

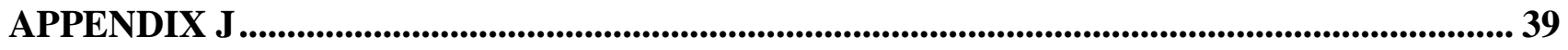

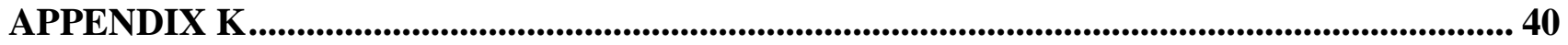




\section{Chapter I: Introduction}

\section{Background and Significance}

Obesity is both preventable and reversible. Adolescents who are overweight or obese have a greater risk of developing serious adult health problems such as heart disease, type 2 diabetes, stroke, certain types of cancer, and osteoarthritis. Obesity also may decrease both life expectancy and quality of life. (US Department of Health and Human Services, 2001).

The map of global obesity of the World Health Organization (WHO) clearly demonstrates that obesity is most prevalent in developed countries (WHO Global Database on BMI, 2010). The United States ranked number one with an overall obesity rate of $30.6 \%$ among adults, a rate which is even higher in the African American adult population. The obesity rate for adults is nearly $50 \%$ for females and $37 \%$ for males (Centers for Disease Control (CDC), 2009). The national obesity rate for adolescents ages $12-19$ years was $18.1 \%$ in the $2007-2008$ period, a significant change from $6.1 \%$ in the early 70 's (CDC, 2009). According to Barlow (2007), these figures have sounded alarms for all involved in the health care of children and adolescents. Obesity is one of the most serious health issues affecting youth, and as a clinical problem has reached epidemic proportions in the United States. The importance of addressing this issue cannot be overstated.

For children and adolescents ages 2-19 years, overweight is defined as a Body Mass Index (BMI)

at or above the $85^{\text {th }}$ percentile, and obesity is defined as a BMI at or above the $95^{\text {th }}$ percentile determined by using CDC growth charts (CDC,2012)[U.S. Preventive Task Force, 2010] Appendices I and J). Obese adolescents most likely will become obese adults (Sedulk et al., 1993). Adolescents will take into adulthood the eating habits and exercise patterns developed during their teen years. In the case of teens who are sedentary and who consume diets high in fat and sugar with few fruits and vegetables, the likelihood is that, without intervention, these behaviors will continue into adulthood.

While Maryland ranks 24th in the nation with an adult obesity rate of $24.6 \%$ overall and an adolescent rate of $12 \%$, Baltimore City leads the state with a $35 \%$ rate of obesity (CDC, 2010). For adolescents within Baltimore City, the aggregate obesity rate is $18.1 \%$, while African American adolescents in the same area have a $30.1 \%$ rate (CDC, 2010).

Multiple cultural issues need to be considered in addressing the issue of overweight and obesity in the urban African American adolescent population. There is a lack of general acceptance of obesity as 
a health issue in the African American population, particularly with regard to the female adolescent. "Although greater acceptance of heavy body ideals may be protective against some eating disorders, it may be a risk factor for obesity and may limit motivation for weight loss or weight control" (Kumanyika et al., 2005, p. 487). Television and billboard advertising in the urban community has a heavy emphasis on sweetened drinks, fast food restaurants, and high calorie snacks (Dietz \&Gortmaker, 1985). In Baltimore City, these advertisements are particularly appealing in their presentations of beautiful young African American women and handsome men having fun while consuming the advertised products (personal observation of P. Setlow, February 25, 2011).

According to the US Census Bureau, African American households have a median income of $\$ 32,584$ compared with $\$ 51,861$ of white households. A limited budget affects the options in food selections for the adults who shop for the family. Grocery stores within walking distance are small and expensive and without adequate affordable supplies of fresh fruits and vegetables. Larger stores with healthier food selections and more affordable prices require a car, which many inner city residents do not have, or access to public transportation, which is limited in Baltimore (Buying into Nutritious Eating. Johns Hopkins Public Health Magazine, 2006).

The cuisine of African Americans traditionally includes yellow and green vegetables, fish, poultry, and beans, nutritious foods, which provide excellent sources of protein, vitamins and antioxidants. Seasonal markets, popular with the families of the target population, provide healthy products including fresh fruits and vegetables. "However, many of the traditional methods of cooking such as deep frying, seasoning with ham or ham hocks, or adding gravy are in conflict with the hearthealthy recommendations to reduce fat and sodium intake" (California Food Guide, 2006, p. 2). Cultural cooking tends to be influenced by southern recipes, which historically are high in starch, sugar, and fat. A popular term for African American food is "soul food", which includes fried chicken, fried pork chops, corn bread, and ribs. These foods are prepared using large quantities of pork fat, butter and salt for flavor.

Adolescent obesity is a challenge for all populations but none more so than for the urban African American adolescent population with its economic disadvantage and influence of ethnicity (Kumanyika, 2005). Because the problem of obesity has reached epidemic proportions with a concurrent increase in preventable chronic diseases as well as a significant impact in economic and human costs, more research is needed. Developing effective programs that are presented in a culturally sensitive manner to address 
overweight and obesity in the African American adolescent population is essential in combating this serious clinical issue.

The author, the associate director of a clinic imbedded within a high school with a population of African American adolescents, was presented with an opportunity to propose a project to address obesity in the identified sample population. In response, Healthy Me was developed and implemented. Healthy $M e$ is a program that provides both nutritional education and physical activity using Creating Opportunities for Personal Empowerment (COPE), a program designed and tested by Dr. Bernadette Melnyk, an internationally known expert on childhood and adolescent obesity. The theoretical framework which guided the project is Pender's Health Promotion Model (HPM) (Pender \& Parsons, 2011). The site for the project was St Frances Academy (SFA), a small Catholic school located in inner city Baltimore serving African American adolescents.

\section{Theoretical Framework}

The Health Promotion Model (Pender \& Parsons, 2011) was used as the theoretical framework to address adolescent obesity. Considerations for choosing this model included a framework that could be applied to studies which promote a healthy lifestyle and that address the unique issues of the adolescent. Frameworks that are based on fear or threats are not effective, particularly if the threats are in the distant future. "Probably the purest form of motivation for health promotion exists in childhood through young adulthood when energy, vitality, and vigor are important to attain but the threat of chronic illness seems remote." (Pender, Murdaugh, \& Parsons, 2002, p. 7). Choosing a theoretical framework applicable to the intervention was based on self-care and health promotion. It is for these reasons that the HPM was chosen. It is a framework widely used in nursing, and although the concepts are numerous, all seem applicable to the topic being addressed.

The HPM is a model that recognizes the multi-dimensional nature of persons as they interact within their environment to pursue a healthy lifestyle. The model focuses on increasing the clients' level of wellbeing. The HPM defines health as a positive dynamic state and not merely the absence of disease. Having concepts and assumptions sets the structure for the model, but also addresses personal influences that can assist the client in regulating his or her own behavior.

The HPM with its explanation and application of concepts addressing adolescent obesity follows in chart form. 


\begin{tabular}{|c|c|c|}
\hline Concepts & Explanation of Concepts & Application of Concepts to the Intervention \\
\hline Personal Factors & $\begin{array}{l}\text { Personal factors which are predictive are: } \\
\text { Biological, for example, pubertal status } \\
\text { Psychological, for example, perceived health status } \\
\text { Sociocultural, for example race or ethnicity }\end{array}$ & $\begin{array}{l}\text { Personal factors to be considered include: pubertal status, perceived health status, and } \\
\text { race, and premature death. Athletes sometimes see themselves as being in positive } \\
\text { states of health while they are actually morbidly obese with co-morbidities. } \\
\text { Adolescents do not see themselves as vulnerable to serious illness or even death itself. } \\
\text { The subject population is African American. Since literature suggests that often this } \\
\text { ethnic group does not view obesity as a problem, that attitude will have to be } \\
\text { addressed. }\end{array}$ \\
\hline $\begin{array}{l}\text { Behavior } \\
\text { Specific } \\
\text { Cognitions and } \\
\text { Affect }\end{array}$ & $\begin{array}{l}\text { Behavior specific variables are a core value of HPM } \\
\text { because these variables can be modified by an } \\
\text { intervention. }\end{array}$ & $\begin{array}{l}\text { A student choosing to bring a healthy lunch rather than fast food would demonstrate a } \\
\text { change in cognition. } \\
\text { Setting individual goals of weight loss would also indicate changes in cognition. } \\
\text { Showing participation and positive responses during class indicates change in affect } \\
\text { toward the topic. If the student were a leader, his/her positive response would } \\
\text { influence other class members. }\end{array}$ \\
\hline $\begin{array}{l}\text { Barriers to } \\
\text { Action }\end{array}$ & $\begin{array}{l}\text { Barriers to action work in two ways. If the barrier is } \\
\text { very high and the commitment to adopt a healthy } \\
\text { behavior is very low, the change is unlikely to occur. } \\
\text { Barriers will also affect intention to engage in a health } \\
\text { promoting behavior }\end{array}$ & $\begin{array}{l}\text { The barriers to action to be considered include the amount of input the subject has in } \\
\text { food choices at home and the behavior of the peer group. If little input is allowed and } \\
\text { motivation for a healthier lifestyle is low, the intention to engage in health promoting } \\
\text { behavior may be lost. Two factors may negate the barrier. One is to have family } \\
\text { involvement, and the second is to adopt a buddy system for members of the subject } \\
\text { group. For example, go to lunch with a buddy from class to a fast foods restaurant and } \\
\text { order a healthy meal. This may be easier to do if more than one subject orders in this } \\
\text { way. Scenarios like this one will be addressed in class. }\end{array}$ \\
\hline $\begin{array}{l}\text { Perceived Self- } \\
\text { Efficacy }\end{array}$ & $\begin{array}{l}\text { Self-efficacy refers to one's belief in one's ability to } \\
\text { carry out a certain behavior. If one has high self- } \\
\text { efficacy, it will impact the perceived barriers by } \\
\text { reducing them. } \\
\text { Self-efficacy motivates healthy behaviors in two ways: } \\
\text { it raises belief in one's ability to perform and lowers } \\
\text { barriers to perform by belief that one can do it. }\end{array}$ & $\begin{array}{l}\text { The students will need reinforcement of their abilities to move toward healthier } \\
\text { activities and lifestyles. Being cognizant of the level of the students (incoming } 9^{\text {th }} \\
\text { graders) will be very important as generally their anxiety level is high and concerns } \\
\text { about their ability to succeed in high school is typical of this group. Activities early in } \\
\text { the program must provide the opportunity for success in order to increase their } \\
\text { perceived level of self-efficacy. }\end{array}$ \\
\hline
\end{tabular}




\begin{tabular}{|c|c|c|}
\hline $\begin{array}{l}\text { Activity Related } \\
\text { Affect }\end{array}$ & $\begin{array}{l}\text { Emotion, action, and the environment affect the } \\
\text { adoption of health promoting behaviors. If the feeling is } \\
\text { positive, the behavior may be repeated again. }\end{array}$ & $\begin{array}{l}\text { The intention of the intervention is to make the atmosphere a positive and pleasant } \\
\text { one, less stressful than regular classes with many goodies provided, not based on } \\
\text { behavioral accomplishments but on participation. These include: tee shirts, healthy } \\
\text { snacks, and pedometers. }\end{array}$ \\
\hline $\begin{array}{l}\text { Interpersonal } \\
\text { Influence }\end{array}$ & $\begin{array}{l}\text { There are three interpersonal aspects that may influence } \\
\text { health promoting behaviors: the influence of significant } \\
\text { others, social support, which may involve emotional } \\
\text { support or perhaps paying for gym membership and } \\
\text { positive modeling behavior from instructors or } \\
\text { classmates. }\end{array}$ & $\begin{array}{l}\text { A concerted effort will be made to include families in the project. If willing, they will } \\
\text { be used as volunteers. A "healthy family meal" will be offered for students and their } \\
\text { families. Asking individual parents who have students with major health issues for } \\
\text { example, morbid obesity, to encourage participation both at home and at school will } \\
\text { motivate the student toward healthier behavior. Teachers and staff will be asked to } \\
\text { model healthy behaviors for the intervention period. }\end{array}$ \\
\hline $\begin{array}{l}\text { Situational } \\
\text { Influences }\end{array}$ & $\begin{array}{l}\text { The environment influences behavior either by choice or } \\
\text { by enticement. A no smoking environment influences } \\
\text { non-smoking behavior and an interesting, attractive gym } \\
\text { with good equipment may entice health promoting } \\
\text { behaviors. }\end{array}$ & $\begin{array}{l}\text { The goal for the capstone project is to have all stakeholders, faculty, staff, and students } \\
\text { are positive influences in regard to healthier lifestyle choices. }\end{array}$ \\
\hline $\begin{array}{l}\text { Commitment to a } \\
\text { Plan of Action }\end{array}$ & $\begin{array}{l}\text { Commitment to an action or process will only occur if } \\
\text { there are no competing demands that cannot be avoided } \\
\text { or resisted. } \\
\text { The commitment must also include strategies for } \\
\text { successful commitment to the plan. If there are no tools } \\
\text { in place to insure the commitment to action, it will } \\
\text { simply be wishful thinking. }\end{array}$ & $\begin{array}{l}\text { Participation in the Healthy Me program is not voluntary, because it is integrated into } \\
\text { PE class. However, assisting participants to make a commitment to a plan of action is } \\
\text { voluntary as is the completion of the capstone questionnaires. Assisting subjects by } \\
\text { providing tools will be necessary to insure commitment to action. These tools include } \\
\text { skills taught that assist in maintaining commitment to action even in the face of } \\
\text { barriers. Individual components of healthy living, for example, eliminating sweetened } \\
\text { beverages, and eating smaller portions will be targeted. }\end{array}$ \\
\hline $\begin{array}{l}\text { Immediate } \\
\text { Competing } \\
\text { Demands and } \\
\text { Preferences }\end{array}$ & $\begin{array}{l}\text { This concept refers to competing demands or } \\
\text { preferences that occur immediately before the planned } \\
\text { health promoting behavior. } \\
\text { An example might be other students asking the student } \\
\text { to go to McDonalds with them when he or she was } \\
\text { headed for a work-out. The point is that an immediate } \\
\text { competing behavior may trump good plans. }\end{array}$ & $\begin{array}{l}\text { Teaching subjects to cope with a competing demand or even preference would assist } \\
\text { the subject in making healthier choices. In reference to the example given, perhaps the } \\
\text { subject could be provided with a ready explanation to resist both the competing } \\
\text { demand and the preference. "I'll meet you there after I work out" or "I'll walk and } \\
\text { meet you there" }\end{array}$ \\
\hline $\begin{array}{l}\text { Behavioral } \\
\text { Outcome }\end{array}$ & $\begin{array}{l}\text { This is the action outcome of HPM, which leads toward } \\
\text { attaining healthy outcomes, improved health, and } \\
\text { maintaining a healthy lifestyle. Additionally, } \\
\text { improvement in quality of life will occur at all stages of } \\
\text { development. This concept relates to the issue that all } \\
\text { groups, adolescents, children, and elderly, can improve } \\
\text { health by adopting a healthier lifestyle and thus improve } \\
\text { the quality of their lives. }\end{array}$ & $\begin{array}{l}\text { The proposed outcome of the capstone project is that the environment will be one of } \\
\text { health promoting behaviors. This would include: continuation of the Healthy Me } \\
\text { program, healthier cafeteria food, and removal of high calorie, high fat snack food and } \\
\text { drink machines from the school. For the individual } 9^{\text {th }} \text { grader, the desired outcome } \\
\text { would be the maintenance of a healthier lifestyle with support from the Health Center } \\
\text { and the school. }\end{array}$ \\
\hline
\end{tabular}




\section{Pender's Health Promotion Model Theory Literature Review}

The HPM used frequently in nursing research provides an excellent framework for the utilization of the COPE/TEEN program. The following are illustrative of the use of the HPM in a variety of health related studies: "Using a Health Promotion Model to Promote Benchmarking” (Welby, 2006), "Social Support and Health Promotion Lifestyles of Rural Women” (Adams, Bowen, Humphrey, \& McAdams, 2000), and “Test of the Health Promotion Model as a Causal Model of Construction Workers' Use of Hearing Protection" (Lusk, Ronis, \& Hogan, 1997). Welby assessed if benchmarks were being used with the goal of promoting standardization of neonatal care. In the project relating to rural women, the relationship between social support and health promotion lifestyles of rural women was examined, and in the last article the use of protective hearing gear among construction workers was researched. As the above examples clearly demonstrate, the HPM is used as a framework for studies spanning many issues and methodologies.

School is the perfect venue for affecting change in adolescent behavior since almost all of the country's teens are in school. Learning about oneself and what constitutes health promoting behaviors can exert a major influence on the development of these behaviors. 


\section{Chapter II: Literature Review and Synthesis}

\section{Search Strategy}

The search strategy to identify the best evidence related to the issue of obesity included a search of Pub Med, CINAHL, Academic Search Complete, and the Cochrane Library. Keywords used for the search included: overweight, obesity, adolescents, African Americans, obesity treatment, nutritional education, exercise, and identification of overweight/obesity in various combinations yielding 32,070 hits. Setting time parameters of 2005 to the present limited the hits to 622. Narrowing the search to peer reviewed journals and clinical trials reduced the number to 78 articles. This number was further reduced by limiting the search to randomized controlled trials (RCT), meta-analyses, and clinical guidelines. A total of 12 relevant articles including two clinical guidelines, (Scottish Intercollegiate Guidelines Network, 2010; August et al., 2008), two meta analyses (Seo \& Sa, 2010; Stice, Shaw, \& Marti, 2007), and eight RCTs (Black et al., 2010; Bernsten et al., 2010 Leite, Milano, \& Cieslak, 2009; Adamo, Rutherford, \& Goldfish, 2010; Doyle et al., 2008; Annesi, Walsh, \& Smith, 2010; Tse \& Yuen, 2009; Melnyk et al., 2007). Each was critically appraised.

\section{Review of Literature}

A critical appraisal was completed on each of the articles using the appropriate appraisal tools, the Agree Research Trust (2006), and the Scottish Intercollegiate Guideline Network (2010). Two applicable clinical practice guidelines resulted from the literature search. One is the Scottish Intercollegiate Guideline Network (SIGN), "Management of Obesity in Children and Young People: A National Clinical Guideline". This guideline updates a previous version from 2003. The objectives of the current guideline were clearly stated, “... to provide evidence-based recommendations on the prevention and the various treatments of obesity in children, young people and adults within the clinical setting" (SIGN, 2010, p. 96). Diagnosis of overweight and obesity should be made using the BMI centile. Recommendations include: school based programs, decrease in dietary intake, increase in physical activity levels, and a decrease in sedentary behaviors including television and computer games. Supporting evidence for all recommendations was identified and graded. As stated earlier, this is an updated version of the guideline and any future modifications of the guideline will be placed on the SIGN website.

The second guideline is "Prevention and Treatment of Pediatric Obesity: an Endocrine Society Clinical Practice Guideline Based on Expert Opinion” (August et al., 2008). This article clearly reports 
on methods, objectives, participants, methods for evaluation of evidence, consensus, and conclusions. The clinical guideline addresses both specific and broad issues pertaining to prevention, diagnosis, and treatments. Additionally, recommendations were made for school board involvement in addressing this problem and for clinicians to be politically active regarding high density, high calorie snack foods marketed to teens. Treatment recommendations included lifestyle modification involving diet and physical activity. Both in this guideline and in the previous one, there is a very strong recommendation for family involvement. It is this recommendation that will be the most challenging to implement in this project.

"The Meta-Analytic Review of Obesity Prevention Programs for Children and Adolescents: Skinny on Interventions that Work" (Stice et al., 2007), and "A Meta-Analysis of Obesity Interventions among U.S. Minority Children" (Seo \& Sa, 2010) were reviewed. The first meta-analysis' strength was in its scope and analysis of all components of the studies selected, however the results only focused on change in BMIs rather than other factors that were considered in the studies reviewed, for example decrease in weight or knowledge of healthy eating. The latter emphasized that programs addressing obesity consisting of three or more components were the more effective ones. "Intervention strategies, such as involving parents, changing lifestyles by integrating desired physical activity, and diet changes into participants' daily routines, considering cultural characteristics, and using interactive computer programs, may be efficacious in preventing or treating obesity among minority children" (Seo \& Sa, 2010, p. 327). It noted that most school based programs only address one or two components and acknowledged that more interventions might pose financial challenges, but reaffirmed that obesity interventions that target minority children need to have multiple components to be effective. The strength of this analysis was in its review of literature of programs that target minority children and adolescents with the effectiveness of each trial quantitatively evaluated. Additionally, statistically there was a strong correlation between the number of components and effectiveness. However a major limitation of this meta-analysis was that of the 40 studies, 28 had either no data on minority participation or one study had no minority children participating. This is either a commentary on lack of research on obesity in minority populations or on the author's choice of research to be included.

An RCT by Adamo et al. (2010) addressed the cost of a program to increase physical activity of overweight and obese participants comparing the use of expensive stationary bikes with built in video games to a control group using stationary bikes while listening to music. Measurements included adherence to the program and energy expenditures of the students. The level of significance was 
$p<0.05$. Both the music and video game condition produced significant improvements in peak heart rate $(\mathrm{HR})(p=0.004)$ (i.e., reduction in peak HR at peak workload), peak workload $(p=0.038)$, and time to exhaustion $(p=0.038)$. This research focused solely on physical activity as students were told not to change their diets. The study gives support for the use of adolescent friendly exercise equipment to promote cardio-function and weight loss in overweight/obese adolescents. Limitations included: a relatively small sample, 15 participants in each group, and limits of generalizability to non-obese adolescents. However, this research would support the reinstatement of physical education into schools. It should also be noted that costly materials are not needed to achieve positive results.

The research focus of a study by Annesi, Walsh, and Smith (2010) was on the relationship between the duration of a program and the most positive outcomes. The comparison was made between 12 (group one) and 24 (group two) week programs to determine the effect of program length on changes in nutrition, physical activity, BMI, and psychological predictors in overweight and obese adolescents at risk for type 2 diabetes. At the end of 12 weeks, test statistic for BMI for group one $\mathrm{t}$ [34] $=0.46 \mathrm{p}=$ $0.64, \mathrm{D}=0.05 ; 95 \% \mathrm{CI}=0.59$ to 0.37 and for group twowas $\mathrm{t}[28]=1.00 ; \mathrm{p}=0.33 ; \mathrm{d}=0.19 ; 95 \% \mathrm{CI}=-$ 0.46 to 0.16 were not significantly different. Following the initial 12 weeks, the group assigned for the additional 12 weeks was given a goal of a 5\% weight loss, which may have influenced the outcome. This RCT was held at the YMCA, and the outcome for the 24 week group was significantly better.

Bernsten et al. (2010) described a program to determine if five months of guided active play in overweight or obese children and adolescents under multi-disciplinary management led to increased physical activity in leisure time, as well as changes in aerobic fitness and body composition. This randomized control trial included 60 obese children or adolescents assigned to either an intervention or control group. From baseline, adjusted physical activity levels increased $(\mathrm{P}=0.4)$ and body fat decreased by $1.8 \%$ ( $\mathrm{p}=0.04)$. Strengths of the study included objective measurements of physical activity using accelerometers and close follow-up of students. Limitations included the short duration of the program and a lack of adherence to active play by students. The dilemma for these researchers was a cut off point for the program as opposed to a longer program with higher attrition.

Black et al. (2010) studied a home based health promotion/obesity prevention program called Challenge Run at a university based medical center. The intervention was based on social cognition theory that included a mentor for each student. At the end of the program, the overweight/obese status declined $5 \%$ in the intervention group and increased $11 \%$ in the control group. An additional strength of the program was its home based orientation, which allowed for interaction with parents or guardians. 
There was a $76 \%$ retention rate in the program over a 2 year period. However its limitations included a lack of generalizability, because the program was designed for low income African Americans, and there were a greater number of overweight and obese categories in the intervention group than in the control group. In addition, the variability in the relationships of the student and mentor may have skewed the results.

A study by Doyle et al. (2008) evaluated the effectiveness of an Internet delivered program addressing weight loss without increasing eating disorders. Eighty overweight students participated for 16 weeks in Student Bodies 2 (SB2), a cognitive behavioral program or in usual care (UC). Outcomes included reduction in body mass index in the SB2 group compared with the usual care group from baseline to post-intervention $\mathrm{p}=.027 \mathrm{BMI} z$-scores were reduced in the SB2 group compared with the UC group from baseline to post-intervention. The SB2 group maintained this reduction in BMI $z$-scores at a 4-month follow-up, but significant differences were not observed because of improvement in the UC group. The SB2 group evidenced greater increases in dietary restraint post-intervention $(p=.016)$ and less improvement on shape concerns at follow-up $(p=.044)$; however these differences were not clinically significant. The SB2 participants reported using healthy eating-related and physical activityrelated skills more frequently than UC participants post-intervention $(p=.001)$ and follow-up $(p=.012)$. Limitations of the study included the fact that changes in BMI might have been due to the normative changes, and additionally all of the participants were African American and severely obese, which may limit generalizability of the study. Another limitation may be the inclusion of students who are uncomfortable with, or do not have access to, the Internet. Additionally, there was no long term follow up for the study.

The objective of the Leite et al. (2009) study was to analyze the effects of physical exercise and nutritional guidance on body composition, physical fitness, and laboratory results (lipids and insulin resistance) among obese adolescents with and without metabolic syndrome. The program consisted of 12 weeks of physical activity and two nutritional guidance sessions with two groups of students, one with metabolic syndrome $(n=29)$ and one without $(n=35)$. Each physical activity session consisted of fifty minutes of indoor cycling, fifty minutes of walking/running, and twenty minutes of stretching three times a week at an unidentified site. The outcome of this program was positive. Obese participants with metabolic syndrome showed significant reduction in total body mass $(\mathrm{p}=0.001)$ and BMI z scores ( $\mathrm{p}<0.001)$. Results showed that $72 \%$ of the adolescents who had been diagnosed with metabolic syndrome resolved this issue. 
Melnyk et al. (2007) completed Phase I and Phase II clinical trials to determine the feasibility of implementing the COPE/Healthy Teens Program for overweight and obese adolescents. There were two phases in the initial research, one conducted to evaluate the safety and feasibility of the program in an urban setting and the second, a pilot research project set in a suburban school. The focus was on weight loss and decrease in BMI. The sample sizes were small, $n=11$ in the urban study and $n=13$ in the suburban area. In phase one in the urban school only one student completed the program and no parents were involved in the In the phase II, a randomly controlled pilot study, the intervention group had an aggregate weight loss of 32 pounds as compared to 11 pounds for the control group. Strengths included a match of group members in Phase II for age, demographics, weight, and BMI. Additionally, using the COPE/TEEN program, which is based on cognitive behavioral theory, was deemed helpful by both researchers and participants in helping students to decrease stress, avoid negative thinking, and thus be more successful in meeting goals including moving toward a healthier lifestyle. Limitations included the possible lack of generalizability to populations in urban and rural areas since the pilot was most successful in the suburbs. A second limitation to the success of the program was the high attrition rate thought to be due to conducting the program after school in all sites. Conflicting demands on students' time that contributed to the high attrition rate in the suburban site were jobs and sports, and in the urban setting, sports, jobs, and the responsibility of caring for younger siblings.

In an RCT, Tse and Yuen (2009) reported the positive effects of health education on diet and physical activity on the total school population of 203 teenagers in Hong Kong. A six month health education program was provided and BMIs, dietary habits, and physical exercise patterns were recorded before and after the program. The teens' knowledge of nutrition and physical activity showed marked gains upon the completion of the program. Three months after the completion of the program there continued to be positive gains in the diets and activity levels of the students. The student body even asked the snack shop to provide healthier snacks. A limitation of this study was the lack of autonomy in participation. Permission to participate in the study was only obtained from the headmaster and parents, not from participants. This may be a confounding factor or it may be a culturally acceptable practice that no assent is required from students of this age.

\section{Synthesis}

The evidence was collected through the evaluation of twelve documents including two clinical practice guidelines, (Scottish Intercollegiate Guidelines Network, 2010); (August et al., 2008), two meta-analyses, (Seo \& Sa, 2010; Stice et al., 2007), and eight RCTs (Black et al., 2010; Bernsten et al., 
2010; Leite et al., 2009; Adamo et al., 2010; Doyle et al., 2008; Annesi et al., 2010; Tse \& Yuen 2009; and Melnyk et al., 2007). Based on the combined results of these studies, programs that treat overweight and obese adolescents using nutritional education and physical activity have a positive impact on the students' ability to lose weight, gain knowledge of healthy eating, increase physical activity, and in some studies, gain physical endurance. However in most RCTs, in both clinical guidelines, and in the two meta-analyses, family involvement was included as a key component of successful programs. Heterogeneity was present across studies for outcomes of weight loss and increased physical activity through programs that offered nutritional education and physical activity. Several programs (Black et al., 2010; Melnyk et al., 2007; Annesi et al., 2010) standardized the presentation of the program to increase internal validity. In addition to providing basic information, a variety of techniques were tested for decreasing weight and or BMI in overweight and obese adolescents. These included the Internet, home visits, and stationary bikes with and without video games attached. One study included the addition of an individual mentor.

In assessing outcomes that include reduction of BMI, normal physiological growth must be considered. All programs had varying degrees of success, and the variety of approaches demonstrates the need for research to identify the evidence based practice that would be most successful in addressing this issue. Research reveals that there is not one program that is most successful, but that programs need to be tailored to groups with varying demographic characteristics.

\section{Congruence of Mission of Organization Site to Project}

The mission of St Frances Academy (SFA) is to address each student academically, physically and spiritually and to guide and nourish them in the spirit of Mother Mary Lange, the founder of the school. By addressing the students with respect and acknowledging their value and potential as human beings while focusing on healthier lifestyles, Healthy $M e$ is in accord with both the philosophy and the mission of the school. Although the Healthy Me project is primarily based on nutritional education and exercise, its approach is sensitive to the adolescent age group and does address through interaction all aspects of the students' lives now and in the future. For example, designing and writing invitations to one's parents for the Healthy Me dinner will afford the students the opportunity to gain social graces and interpersonal awareness.

While it was not in the purview of this project to change the policies of the school, the project director will present findings from the project to the administrative team of SFA, the board of directors 
of St Frances Academy, and the board of directors of the Coppin Clinic at St Frances to advocate for a physical education /health class to become part of the regular curriculum at St Frances Academy. Student aggregate baseline health information will be included in the presentations to the above boards.

The administrators of the Academy granted permission to incorporate the intervention into the school day for ninth grade students substituting Healthy Me for one religion class since there is no health class at the school. Fifteen sessions were presented throughout the spring semester. The religion teacher was supportive of the curriculum change and offered assistance if it were needed. Consent forms not collected directly by the NP were placed in their sealed envelopes as they were returned to the school. Individual assent forms were collected as measurements were obtained.

\section{Goals and Objectives}

The primary goals of the Healthy Me project were threefold. The first was to address the presumed deficit in knowledge of what constitute a healthy lifestyle including knowledge of good nutrition and the importance of regular physical exercise and to fill in the gaps that exist in that knowledge for $9^{\text {th }}$ grade students at St Frances Academy. The second goal was to assist overweight and obese adolescents to decrease their weight and BMI through health education and physical exercise. The third goal is the continuation of the emphasis within the school on healthy living for the students, and all members of the school community. 


\section{Chapter III: Methodology}

\section{Project Design}

This pilot project was a one group, pretest posttest quasi experimental design to investigate the effectiveness of Healthy $M e$ intervention based on the COPE/TEEN with a convenience sample of $9^{\text {th }}$ grade students at St Frances Academy, an urban high school in Baltimore, Maryland. Prior to initiation, it was submitted to the West Virginia University Institutional Review Board (IRB). It was reviewed by the IRB, approved and determined to be expedited. It was then submitted to Coppin State University IRB, approved and determined to be expedited.

\section{Resources}

Personnel with a variety of responsibilities were needed for the success of the project. Healthy Me was conducted by the Nurse Practitioner/Doctor of Nursing Practice (DNP) student. Multiple responsibilities were involved in this position. They included: supervision of the project, teaching nutritional classes and assisting with physical education classes. Additionally, purchasing needed equipment and maintaining the budget were the project director's responsibilities. (See Appendix H)

\section{Procedure}

This capstone project was designed to evaluate the effectiveness of Healthy Me, based on the COPE/TEEN intervention. After obtaining written consents from the parents and assents from the students, students were enrolled in the study. At baseline students were given the following questionnaires to complete: Healthy Lifestyle Belief Scale (HLBS), Healthy Lifestyle Choice Scale (HLCS), Nutritional Knowledge (NK), and Youth Adolescent Questionnaire (YAAQ). Anthropometric measurements of height, weight, waist and hip circumference were obtained by the health aide on all students From that data, percentile placement on CDC growth charts and waist to hip ratios were obtained. Following these initial assessments, Fifteen fifty five minute sessions of nutritional education and physical exercise opportunity were provided. Included in these were two sessions of Yoga and two sessions of Zumba. Students were given T-Shirts (Appendix F) to identify their participation in the Healthy Me program and as in Sveinung et al.,(2010), pedometers were given to students to increase their awareness of their daily steps or lack of steps. Didactic sessions included: energy balance, ways to increase activity, obtaining one's heart rate, food groups, reading labels, awareness of media and advertising influence on food choices, supersizing, and social eating. Following completion of the sessions, all pre-intervention assessments and surveys were repeated. Activities included large ball play, 
basketball, hula hoops, jump rope, and walking both in gym and outside as the weather warmed. The project ended with a Healthy Me dinner for students and their families. At that time, a cookbook with healthy recipes was presented to families of students involved in project.

\section{Instruments}

The four instruments used in this project were Healthy Lifestyle Belief Scale (HLBS), Healthy Lifestyle Choice Scale (HLCS), Nutritional Knowledge (NK), and Youth Adolescent Activity Questionnaire (YAAQ). (See appendices B, C, D, E) The first two were evaluated using the paired t-test and the last two with Chi-Square.

The HLBS measured the teens' beliefs about their ability to lead a healthy lifestyle (B. Melnyk, personal communication, 2012). This is a 16-item instrument measured on a 5-point Likert scale ranging in answers from 1- strongly disagree to 5 - strongly agree. This questionnaire relates to one's beliefs about maintaining a healthy lifestyle, such as "I believe I can be more active." Face validity was established with 10 teens and content validity with eight adolescent experts. Factor analysis with more than 400 high school adolescents supported construct validity (B. Melnyk, personal communication, 2012). The Cronbach's alpha value for the pre-intervention belief scale was 0.88 and for the post 0.95 , falling above the 0.70 cutoff value. With the exception of the kurtosis for the post-test scale, the items were normally distributed.

The Healthy Lifestyles Behavior Scale for Teens measured the behavior of the teen participants. This 16-item instrument, developed by researchers who created the COPE/TEEN intervention, utilizes a 5-point Likert scale to answer questions, such as "I exercised regularly", or "I talked about my worries or stressors." Eight adolescent health experts established content validity, while face validity was established with 10 teens according to Melnyk, (2012). Construct validity was supported through factor analysis from data in the preliminary study by Melnyk, (2012). This measurement was taken at baseline and at the end of 15 week intervention. The Cronbach's alpha value for the pre-intervention behavior scale was 0.88 and for the post was 0.91 , exceeding the 0.70 cutoff value.

The nutrition and activity scales measured the students' knowledge of good nutrition and benefits of exercise. The Cronbach's alpha value for the pre-intervention nutrition scale was 0.77 and for the post was 0.86 . The Cronbach's alpha value for the pre-intervention activity scale was 0.73 and for the post was 0.59 . 


\section{Budget}

The investigator developed a budget plan to project and account for the cost of the pilot project, which was covered by grant funds. The investigator's time, the clinic and classroom space were donated. Other costs included: printing of cookbooks, the Healthy Me dinner, purchase of license to use COPE/TEEN program, and compensation for Yoga and Zumba teachers. The budget was adjusted during the course of the project due to situations out of the control of the investigator. For example, the original plan was to have each group prepare and serve their own dinner to family members, but because of scheduling difficulties involving the school kitchen, it was necessary to have one catered dinner with the groups combined. (Appendix H)

\section{Evidence of Key Site Support}

The site for the implementation of the capstone project was St Frances Academy, a small Catholic school in the center of Baltimore. Discussions had been ongoing with administration, faculty, and staff at the school because of the growing awareness of the issues of overweight and obesity affecting the student population. The school demonstrated its support both by a signed letter of support and by placing the project within a regularly scheduled class time in the school day. (Appendix A) 


\section{Chapter IV: Results}

\section{Characteristic of Sample}

After obtaining both parental consents and student assents, $699^{\text {th }}$ grade students at St Frances Academy were included in the study out of a possible population of 81 students (85\%). Only one student declined to participate despite having parental consent to do so. All were African American with ages ranging from 12.11 years to 15.1 years, $14 \%$ or 7 of whom were female and $86 \%$ or 48 were male. Fifty two students completed both pre and post anthropometric measurements while the number who completed all four pre and post questionnaires was 21. Possible explanations for this were absences, parental withdrawal or expulsion from school, or early dismissal due to participation in sports. The differences in completion of questionnaires and anthropometric measurements may be explained by the fact that measurements were taken by staff privately in the clinic, but questionnaires were completed as a group during class time. All $9^{\text {th }}$ grade students were provided with nutritional information and physical exercise opportunities, snacks and an invitation to the Healthy Me dinner regardless of their status with the study.

The first goal of the project was to impart knowledge of healthier eating by increasing the nutritional knowledge of the participants in Healthy Me through presenting content in the group sessions serving healthy snacks, lunch and the dinner at the conclusion. This study demonstrated the students' increasing knowledge of healthier eating and overcoming barriers to accomplish this. Examples of results of survey questions relating to nutrition are in Table 1. Table 2 demonstrates the improvement in healthy beliefs and healthy choice at a statistically levels, $\mathrm{p}=(007)$ and $\mathrm{p}=(003)$ respectively. 
Table 1

Selected Questions on Nutrition

Questionnaire: People need to drink 3 large glasses of milk per day

\begin{tabular}{|l|c|c|c|c|c|}
\hline & Value & df & $\begin{array}{c}\text { Asymp. Sig. (2- } \\
\text { sided) }\end{array}$ & $\begin{array}{c}\text { Exact Sig. (2- } \\
\text { sided) }\end{array}$ & $\begin{array}{c}\text { Exact Sig. (1- } \\
\text { sided) }\end{array}$ \\
\hline Pearson Chi-Square & 11.0 & 4 & .026 & .011 & \\
Likelihood Ratio & 11.2 & 4 & .024 & .023 & .015 \\
Fisher's Exact Test & 10.0 & & & .009 & .007 \\
Linear-by-Linear Association & 6.7 & 1 & .010 & & \\
N of Valid Cases & 41 & & & & \\
\hline
\end{tabular}

Question: It is better to broil foods than to fry them.

\begin{tabular}{|l|c|c|c|c|c|}
\hline & Value & df & $\begin{array}{c}\text { Asymp. Sig. (2- } \\
\text { sided) }\end{array}$ & $\begin{array}{c}\text { Exact Sig. (2- } \\
\text { sided) }\end{array}$ & $\begin{array}{c}\text { Exact Sig. (1- } \\
\text { sided) }\end{array}$ \\
\hline Pearson Chi-Square & 8.6 & 4 & .073 & .051 & \\
Likelihood Ratio & 9.0 & 4 & .061 & .068 & .040 \\
Fisher's Exact Test & 8.3 & & & .565 & .334 \\
Linear-by-Linear Association & 0.3 & 1 & .548 & & \\
N of Valid Cases & 41 & & & & \\
\hline
\end{tabular}

Question: Canned soups have a healthy amount of salt in them

\begin{tabular}{|l|c|c|c|c|c|}
\hline & Value & df & $\begin{array}{c}\text { Asymp. Sig. (2- } \\
\text { sided) }\end{array}$ & $\begin{array}{c}\text { Exact Sig. (2- } \\
\text { sided) }\end{array}$ & $\begin{array}{c}\text { Exact Sig. (1- } \\
\text { sided) }\end{array}$ \\
\hline Pearson Chi-Square & 10.0 & 4 & .040 & .035 & \\
Likelihood Ratio & 11.3 & 4 & .023 & .040 & .047 \\
Fisher's Exact Test & 9.0 & & & .137 & .081 \\
Linear-by-Linear Association & 2.4 & 1 & .124 & & \\
N of Valid Cases & 43 & & & & \\
\hline
\end{tabular}

*Fisher's exact test was calculated due to expected cell counts less than five within chi square analyses.

Table 2

Belief and Behavior Scales

\begin{tabular}{|l|l|l|l|l|l|l|}
\hline Measure & N & M1 (SD) & M2 (SD) & t & df & $P$ \\
\hline Belief Scale & 36 & $3.3(0.9)$ & $3.9(0.8)$ & & 30 & 0.007 \\
\hline $\begin{array}{l}\text { Behavior } \\
\text { Scale }\end{array}$ & 31 & $3.1(0,7)$ & $3.8(0.5)$ & & 20 & 0.003 \\
\hline
\end{tabular}

The second goal was to affect the students who were overweight or obese to decrease their weight and BMI. Many factors need to be considered when analyzing data for adolescents' weight and BMI. The total weight gained by all students in the study was 122.5 pounds and lost was 42.4 pounds. Thirty students gained weight and seventeen lost weight. Fourteen students remained the same weight. Despite the large discrepancies between students' weight gain and loss in this project, many students decreased their BMI. Two students reduced their BMI from overweight to normal category and two 
students from obese to overweight during the course of the program. In addition, one student went from underweight to normal weight. (See Table 3) Hip to waist ratios are another indication of overall health risk and showed positive change during the project.

Table 3

Weight Categories

\begin{tabular}{|c|c|c|c|c|}
\hline \multirow[b]{2}{*}{ Percentile Category } & \multicolumn{2}{|c|}{ Time 1} & \multicolumn{2}{|c|}{ Time 2} \\
\hline & Count & Percent & Count & Percent \\
\hline Category 1 (Underweight) & 2 & $4 \%$ & 1 & $<1 \%$ \\
\hline Category 2 (Healthy Weight) & 27 & $55 \%$ & 29 & $59 \%$ \\
\hline Category 3 (Overweight) & 10 & $20 \%$ & 8 & $16 \%$ \\
\hline Category 4 (Obese) & 10 & $20 \%$ & 8 & $16 \%$ \\
\hline
\end{tabular}

Table 4

Weight, Height, and BMI

\begin{tabular}{|l|c|c|c|c|c|c|}
\hline Weight & 52 & $158.7635(45.427)$ & $160.9923(44.97735)$ & -1.703 & 51 & .095 \\
\hline Height & 52 & $66.4692(4.1)$ & $67.85(3.7)$ & -3347 & 51 & .002 \\
\hline BMI & 51 & $73.2745(25.67962)$ & $70.0784(23.41525)$ & 1.098 & 50 & .277 \\
\hline
\end{tabular}

Table 5

Waist, Hip, and Hip to Waist Ratio

\begin{tabular}{|l|l|l|l|l|l|l|}
\hline Hip & 47 & $40.0532(6.34449)$ & $38.80805(5.89634)$ & 2.263 & 46 & .028 \\
\hline $\begin{array}{l}\text { Waist } \\
\text { circumference }\end{array}$ & 47 & $33.3723(6.12503)$ & $33.6809(5.91739)$ & -.773 & 46 & .443 \\
\hline Hip to waist & 47 & $.8413(.09357)$ & $.8438(.10948)$ & -.146 & 46 & .885 \\
\hline
\end{tabular}

The majority of students willingly participated in the exercise component of Healthy Me. All students were required to participate. Those who tried to be bench sitters were asked to walk the gym. Participation went up and stamina increased for sprints, push-ups, and sit-ups.

Table 6

Exercise

\begin{tabular}{|l|l|l|l|l|l|l|}
\hline Activity & Number & Mean 1 (SD) & M 2 (SD) & t & Df & $p$ \\
\hline Sprints & 43 & $11.6793(1.53122)$ & $12.4795(3.09720)$ & 1.560 & 42 & 0.126 \\
\hline Push ups & 41 & $28.1268(16.44717)$ & $320488(11.71100)$ & 1.729 & 40 & 0.092 \\
\hline Sit Ups & 42 & $27.8571(14.32135)$ & $33,4762(11.95977)$ & 3.412 & 41 & 0.001 \\
\hline
\end{tabular}

The final goal was to modify the atmosphere of the SFA to one of a healthy living milieu. The program has been incorporated into the school curriculum and has influenced both students and 
teachers, and by the very presence of the program, there was an improved awareness of the need for healthy living at St Frances Academy. A concrete example of this is the administration's commitment to removing snack and soda machines in return for this writer submitting a grant application entitled Healthy Hallways. In the past when the subject was addressed, the response had been that the income was needed. The grant has been awarded to the clinic at St Frances.

Thirty seven or $74 \%$ of adult family members or guardians of Healthy Me students attended the dinner that concluded the program. Other students and their families were also invited, and attended for a total of 71. Additionally, 12 faculty and staff members attended to demonstrate their support of the program. At that time, parents and guardians comments were solicited about the program. Comments included how much information about cooking the students had learned as well as the ways to eat healthier without spending more money. Several families commented that they were more active not only with their SFA student but also with their younger children. All parents and staff expressed appreciation for the cookbooks and said they found some of their favorite recipes in the cookbooks. 


\section{Chapter V: Discussion, Summary and Implications}

This chapter will include a discussion and summary of the findings including congruence with the theoretical framework, strengths, and limitations, implications for practice, recommendations, and conclusion.

\section{Congruence with Theoretical Framework}

The HPM is a model that recognizes the multi-dimensional nature of persons as they interact within their environment to pursue a healthy lifestyle. The location of the project was a school that purports to teach not just academics, but a way of life which includes healthy behaviors. This atmosphere is congruent with the chosen framework.

A behavioral outcome of the HPM is the action outcome, which leads to improved health and maintaining a healthy lifestyle. An outcome of this project has been that the administrators of SFA have agreed to another program, Hallways to Health, which is a funded national program for school based health centers. Three programs in Maryland have been chosen, including the one at SFA, which will expand on Healthy Me to include faculty, staff, coaches, and parents. The students who remain at SFA will be $10^{\text {th }}$ graders and will benefit from additional programs addressing their health.

Situational influences, including the environmental influence, are positive influences toward a healthier lifestyle for all students. As has been demonstrated, the administration is supportive of this project, and has been a positive influence in promoting healthier lifestyles for students. There is strong congruence between the theoretical framework and the ideal espoused by the project site research of Annesi et al. (2010) showed that a program with a longer duration yielded better results. This would support having a program incorporated into the school curriculum for the entire school year.

\section{Discussion}

The purpose of this capstone project was to evaluate the effectiveness of Healthy Me, a COPE Healthy Lifestyles TEEN program on a $9^{\text {th }}$ grade health class in an urban high school. Anthropometrics, and healthy lifestyles beliefs and choices outcome measures were examined to determine the effectiveness of the program. The outcomes of interest included weight, BMI, BMI percent, physical activity, and healthy lifestyles beliefs and behavior. Both student and parent evaluation of the program was obtained through comments made by each group at the conclusion of the program during the 
Healthy Me dinner. Se \& Sa (2010) strongly recommended the importance of involving parents to address student overweight and obesity.

There were two very strong components to the project, the COPE/TEEN program with its manualized intervention and the placement of the classes within the school day. Using the COPE program provided a standardized format which has been tested in many other programs and has good reliability and validity. The program developed by Dr Bernette Melnyk is currently being used during the school day in high schools in Arizona for thousands of participants (Personal information from Dr Melnyk, 2012). Many programs including Dr Melnyk's initial pilot found that programs, after school hours, had a large attrition rate due to competing demands on teens' time and focus. Ninth graders were

chosen so that the students could be followed throughout their high school years. While it was probably a liability due to their immaturity, it will be an asset to follow the students who remain at SFA throughout their high school years.

\section{Weight and BMI Categories}

Forty nine students lost a total of 42.4 pounds and gained 122.5 pounds during the Healthy Me program. Twenty seven students $(55 \%)$ began and ended the program in the healthy weight category. Twenty nine students (59\%) were in the healthy weight category at the end of the program because of movement from the overweight program of two students. There was other positive movement between categories. Of the two underweight students, one moved into the healthy weight category and two of the four obese students moved into the overweight category. These changes were calculated using CDC growth charts.

To decrease BMI or BMI percents, either enough weight must be lost or the individual must grow taller to see a notable difference. Although the manualized program only consisted of 15 sessions, the program's duration was five months because of school closings, holidays, and spring breaks.

The school schedule posed a problem with continuity with both time off and placement of schedules. School was closed for a long Easter break, conference days and Homecoming. The lack of reinforcement during this time may have limited more positive results. Two classes of Healthy Me were held on Mondays and two on Wednesdays so often the groups were not in sync, which may have contributed to some of the skewed statistics. 


\section{Activity/Physical Endurance}

Physical exercise was an important component of the program. As in Sveinung et al. (2010), the students were given pedometers to increase their awareness of the number of steps taken each day. Giving the students pedometers was to be one measure of activity by the students outside of school. Bernsten et al. (2010) wanted to show correlation between an activity program and an increase in leisure time physical activity as was the hope in this project of using pedometers. However, pedometers were lost, broken or forgotten. Many students reported being more active, but it could not be documented. As a group, the participating students developed increased stamina as evidenced by the increase in sprints, pushups, and sit ups, but only the sit ups increased to a statistically significant number, $(\mathrm{p}=0.001)$.

Activities included large ball play, basketball, hula hoops, jump rope, Yoga and Zumba and walking both in the gym and outside as the weather warmed. Most students preferred basketball, but could be persuaded to engage in other activities by rewarding them with an occasional basketball session. The problem with always playing basketball is that the students who were not particularly active or into sports would try to sit in the bleachers. While some of the students were playing basketball, others were given jump ropes, hula hoops or walking laps for their activity. As indicated in Adamo et al. (2010) equipment used in addressing obesity does not need to be expensive to yield positive results, but should hold the interest of the students.

Didactic sessions included: energy balance, ways to increase activity, obtaining one's heart rate, food groups, reading labels, awareness of media and advertising influence on food choices, supersizing, and social eating.

\section{Healthy Lifestyles Beliefs and Behavior}

The results of this capstone project indicate that the COPE based Healthy Me program is an effective school based intervention and has a positive influence on $9^{\text {th }}$ grade students' ability to lead a healthier lifestyle. There was a statistically significant increase in healthy belief and behaviors scales for the students in the program, $\mathrm{p}=(007)$ and $\mathrm{p}=(003)$ respectively. Because of the commitment of the school to this project and having had the Healthy Me program during the past academic year, the clinic which directed the program was awarded a $\$ 45,000$ annual grant for two years to follow up with an expanded program for the school. 


\section{Limitations of the Project}

There were several limitations to the current study that may have decreased the number of significant results obtained. Being placed within the school day was positive but it created a barrier to complete participation. The school schedule has been devised to minimize the number of classes missed by students who participate in sports. To accomplish this, there are two alternating schedules, blue week and gold week. Therefore, A period (8:20 am) during blue week is F period (1:50) during gold week. Students playing sports missed the last afternoon class if they had an away game.

What appeared to be an issue with subject fatigue involving completing the four questionnaires was actually an artifact of below grade reading levels for some of the students. The surveys were rated on a sixth grade reading level, but some of the SFA students were reading on an even lower level. Had there been awareness of this factor earlier in the project, an adjustment could have been made to read all the statements to all participants. However, doing so in mid-semester would have compromised the project.

During the course of the school year there were a fluid number of $9^{\text {th }}$ graders, many of whom left the school because of poor grades, misbehavior, or lack of family funds. While the school is a school of second chances for many students and most students receive partial or full scholarships, grades must be maintained, behavior must be appropriate, and tuition paid. The school also accepts new students throughout the year, but they could not be included in the study data although they participated in class. Other students left throughout the school year, some as late as early May. Ninth graders as a group are coming into adolescence, and there were times when their group behavior interfered with absorbing as much information as possible during the didactic portion of the classes. However, most of the students were interactive during the sessions and found the sessions to be informative and helpful in learning how to live a healthy lifestyle.

\section{Implications of Project}

The overall missions of both the Coppin Clinic and St Frances Academy are to address the individual student in a holistic manner. This project demonstrated its effectiveness when applied during the school day as part of the usual curriculum, and could be duplicated in other clinics located within schools. The evidence obtained in this program in addressing adolescent overweight and obesity in the African American community can be duplicated within school based clinics. It may also be duplicated in general clinics for children and adolescents. 


\section{Implications for Doctorate of Nursing Practice (DNP)}

This pilot project incorporated DNP essentials, and utilized scientific underpinnings and evidence based practice to promote awareness of the need for programs that will address overweight and obesity, and knowledge and activity requirements for a healthy lifestyle in the African American adolescent. Continuing education on clinical practice guidelines and evidence based research on adolescent obesity should be undertaken to decrease health care cost and, most importantly, improve the health of adolescents now and in their futures.

In practice, even when not located within schools, DNPs should address both nutritional and exercise requirements for healthy lifestyles as well as overweight and obesity in their adolescent populations. Referrals to local programs are important, but of most importance is the recognition by DNPs of this issue as a threat to a happy and healthy life.

\section{Recommendations}

Based on the experience of this investigator, recommendations include continuing research on the topic of overweight and obesity, particularly with minority populations who are disproportionately affected by these conditions. Research should also be tailored to specific locales whether it be rural or urban as there are differences in attitudes, beliefs, and practices. Additionally, all school based health clinics should make an effort to provide programs which address the important issue of overweight and obesity for all students and directly supervise those students who are obese. The latter group of student should be monitored on a regular basis and provided with the necessary dietary surveillance. There should be a strong effort to involve the whole school to influence the healthier living atmosphere as Tse and Yuen (2009) sis in their study and was done in this capstone project.

\section{Conclusion}

Adolescent overweight and obesity takes a high toll in human suffering and in its cost to the health care system. The effect on adolescents in the present is one of negative physiological and psychological responses and portends increasingly negative responses in the future as co-morbidities develop, the quality of life decreases, and the life span is shortened. Prior research has not demonstrated success in any one program addressing the issue of obesity in all demographic populations. Bernstein (2010) recommends using a multidiscipline approach. Research may reveal that there is not one program that is most successful, but that programs need to be tailored to groups with varying demographic characteristics. Normal physiological growth must be considered in planning interventions with 
adolescents. Additionally, it may be true that a program must be tailored specifically to the adolescent population and placed within the school day to be successful. The COPE/TEEN program has had success in decreasing weight and BMI and increasing knowledge related to a healthy lifestyle, but was not successful when offered in an after school venue.

It must be noted however that the program that is covered in this paper as well as other programs is not sufficient alone to address this national epidemic. Many social issues must also be addressed. For example, Joel Gittlesohn $\mathrm{PhD}$, assistant professor and director of the International Health and Center for Human Nutrition at the Johns Hopkins Bloomberg School of Public Health, is developing a series a corner stores in low income areas that will offer healthier foods to local residents.

This project demonstrated the effectiveness of the program when applied during the school day as part of the usual curriculum. Healthy Me was successful for some students in addressing the issues involved and in modifying the atmosphere of the site for the $9^{\text {th }}$ grade students at St Frances Academy. As a result of this project, the efforts to address this important issue will continue through Hallways to Health, the new grant program awarded to the Coppin Clinic at St Frances. 


\section{References}

Adamo, K. B., Rutherford, J. A., \& Goldfish, G. S. (2010). Effect of interactive video games cycling on overweight and obese adolescent health. Applied Physiology of Nutrition Metabolism, 35, 805815.

Adams, M.H., Bowen, A.G., Humphey, D.S., \& McAdams, L.B. (2000, April).Social support and health promotion lifestyle of rural women. Retrieved July 15, 2012 from http://Online Journal of Rural Nursing and Health Care

Annesi, J. J., Walsh, A. M., \& Smith, A. E. (2010). Effects of 12 and 24 week multimodal intervention on physical activity, nutritional behaviors, and body mass index, and its psychological predictors in severely obese adolescents at risk for diabetes. The Permanente Journal, 14(3), 297-37.

August, G. P., Caprio, S., Fennoy, L., Kaufman, F. R., Lustig, R. H., \& Montori, V. M. (2008). Prevention and treatment of pediatric obesity; an endocrine clinical practice guideline based on expert opinions. Journal of Clinical Endocrinology \& Metabolism, 93(12), 4576-4599.

Barlow, S.E, (2007). Expert committee recommendations regarding the prevention, assessment, and treatment of child and adolescent overweight and obesity. Pediatics, 97, 5164-5188.

Bernsten, S., Mowinckel, P., Carlsen, K. K., Kolsgaad, M., Joner, G., \& Anderson, S. (2010). Obese children playing toward an active lifestyle. International Journal of Pediatric Obesity, 5, 64-71.

Black, M. M., Hager, E. R., Le, K., Anliker, J., Arteaga, S. S., DiClemente, C., \& Wang, C. (2010). Challenge! Health promotions/obesity prevention membership model among urban black adolescents. Pediatrics, 126, 280-288.

Buying into nutritious eating (2006). Johns Hopkins Public Health Magazine, , .

California Food Guide: Fulfilling the Dietary Guidelines for Americans (2006) Healthy and dietary issues affecting African Americans. Retrieved April 1, 2011, from http://www.dhes.ca.gov

Centers for Disease Control (2009). National health and nutrition examination. Retrieved March 12, 2010, from http://www.cdc.gov/nchs/data/hestat/obesity.

Centers for Disease Control (2010). Obesity. Retrieved February 22, 2012, from http://www.cdc.gov/obesity/defining.html

Dietz, Jr, W. H., \& Gortmaker, S. L. (1985). Do we fatten out children at the television set? Obesity and television viewing in children and adolescents. Pediatrics, 75, 807-812.

Doyle, A. C., Goldschmidt, A., Huang, C., Winzelberg, A. J., Taylor, C. B., \& Wilfley, D. E. (2008). Reduction of overweight and eating disorder symptoms via the Internet in adolescents: a Randomized control trial. Journal of Adolescent Health, 43, 172-179.

http://www.cdc.gov/obesity/childhood/basics.html

Kindle Location 3353 
Kumanyika, S. K., Shults, J., Fassbender, J., Whitt, M., Brake, V., Kallan, M.,...Bowman, M. (2005). Outpatient weight management in African American the healthy eating and lifestyle program (HELP) study. Preventative Medicine, 41, 488-502.

Leite, N. L., Milano, G. E., \& Cieslak (2009). Effects of physical and nutritional guidance on metabolic syndrome in obese adolescents. Brazilian Journal of Physical Therapy, 13(1), 73-81.

Lusk, S. L., Ronis, D. L., \& Hogan, M. M. (1997). Test of health promotion of construction workers' use of hearing protection. Research in Nursing \& Health, 29, 183-194.

Melnyk, B. M., Small, L., Morrison-Beedy, D., Strasser, A., Spath, L., \& Kriepe, R.,...O'Haver, J. (2007). The cope healthy lifestyle teen program: Feasibility, preliminary efficacy \& lessons learned from an afterschool intervention with overweight adolescents. Journal of Pediatric Health Care, 5, 315-322.

Pender, M. J., \& Parsons, M. A. (2011). Health promotion in nursing practice (6 ed., Rev.). Upper Saddle River, New Jersey: Prentice-Hall.

Pender, N., Murdaugh, C., \& Parsons, M. A. (2002). Health promotion in nursing practice (4th ed.). Upper Saddle River, NJ: Prentice-Hall.

Scottish Intercollegiate Guidelines Network (2010). Management of Obesity in Children and Young People: A national clinical guideline. Retrieved September 14, 2010, from www.sign.ac.uk

Sedulk, M. K., Ivery, D., Coates, R. J., Freedman, D. S., Williamson, D. F., \& Bryers, T. (1993). Do obese children become obese adults: A review of the literature. Preventative Medicine, 22(2), 167-177.

Seo, D. C., \& Sa, J. (2010). A meta-analysis of obesity interventions among U. S. minority children. Journal of Adolescent Health, 46, 309-323.

Stice, E., Shaw, H., \& Marti, C. N. (2007). Meta-analytical review of obesity prevention programs for children and adolescents: the skinny on interventions that work. Psychological Bulletin, 132(5), 667-691.

The Agree Research Trust (2006). Retrieved November 28, 2010, from www.agreetrust.org treatment of child and adolescent overweight and obesity. Pediatrics 97, 5164-5188.

Tse, M., \& Yuen, D. (2009). Effects of providing a nutrition education program for teenagers: dietary and physical activity patterns. Nursing \& Health Sciences, 11(2), 160-165. Retrieved from CINAHL with Full Text database.

US Census Bureau (2012). Table 690. Money income of households-percent distribution by income level, race, and hispanic origin, in constant (2009) dollars: 1990 to 2009. Retrieved June 29, 2013, from http://www.Census.govcompendia/statab/2012tables/1250691.pdftables

U.S. Preventative Task Force (2010). Screening for obesity in children and adolescents: U.S. preventative task force recommendation statement. Pediatrics, 125, 361-367. 
U.S. Department Of Health And Human Services. (2001). The Surgeon General's call to action to prevent and decrease overweight and obesity. Washington, DC: U.S. Government Printing Office.

US Census Bureau (2012). Table 690. Money income of households - percent distribution by income level, race, and hispanic origin, in constant (2009) dollars: 1990 to 2009. Retrieved June 29, 2013, from http://www.Census.govcompendia/statab/2012tables/1250691.pdftables

Welby, J. (2006). Using a health promotion model to promote benchmarking. Paediatric Nursing, 18, 636.

WHO (n.d). Global data base on BMI. Washington, DC: U.S. Government Printing Office. Retrieved February 22, 2011, from http://www.int/bmi/index.jsp

Wilhelm, G. (2006). Buying in to nutritious eating. Magazine of Johns Hopkins Bloomberg School of Public Health, , 1-1. 


\section{Appendix A}

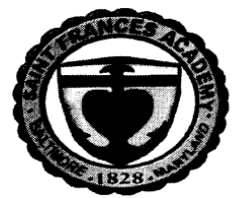

St Frances Academy

501 East Chase Street

Baltimore, Maryland 21202

To Whom It May Concern

I am writing to acknowledge the full support of myself and of St Frances Academy for the Healthy Me program to be offered to members of the incoming ninth grade class in the academic year of 2012-2013. It is my understanding that providing this program is a component of the Doctorate of Nursing Practice requirement for Ms. Patricia Setlow, the Nurse Practitioner and the Associate Director of the Coppin Clinic at St Frances. We look forward to the project being implemented and its being successful for our students.

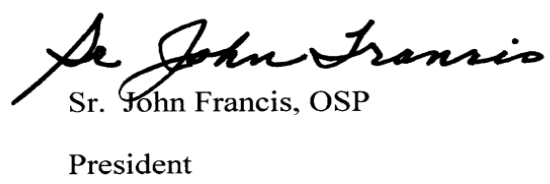

Telephone 410-539 Facsimile 410-685-2650 Web address www.sfaacademy.org Info@sfaacademy.org "Continuing the legacy of its foundress, Mother Mary Lange, in providing the immediate neighborhood and the Baltimore area with faith in God's Providence dignity and uniqueness" 


\section{Appendix B}

Healthy Lifestyles Belief Scale for Teens

\section{Pre/Post Questions}

Code \#

Below are 16 statements that relate to your overall health and well-being. There are no right or wrong answers to the following statements. Please circle the number that best describes your agreement or disagreement with each statement.

\begin{tabular}{|c|c|c|c|c|c|c|}
\hline & & $\begin{array}{l}\text { Strongly } \\
\text { Disagree }\end{array}$ & Disagree & $\begin{array}{l}\text { Don’t } \\
\text { Know }\end{array}$ & Agree & $\begin{array}{l}\text { Strongly } \\
\text { agree }\end{array}$ \\
\hline 1 & $\begin{array}{l}\text { I am sure that I will do what is best to } \\
\text { lead a healthy life }\end{array}$ & 1 & 2 & 3 & 4 & 5 \\
\hline 2 & $\begin{array}{l}\text { I believe that exercise and being active } \\
\text { will help me to feel better about myself }\end{array}$ & 1 & 2 & 3 & 4 & 5 \\
\hline 3 & $\begin{array}{l}\text { I am certain that I will make healthy } \\
\text { food choices. }\end{array}$ & 1 & 2 & 3 & 4 & 5 \\
\hline 4 & $\begin{array}{l}\text { I know how to deal with things in a } \\
\text { healthy way that bother me. }\end{array}$ & 1 & 2 & 3 & 4 & 5 \\
\hline 5 & $\begin{array}{l}\text { I believe that I can reach the goals that } \\
\text { I set for myself. }\end{array}$ & 1 & 2 & 3 & 4 & 5 \\
\hline 6 & $\begin{array}{l}\text { I am sure that I can handle my } \\
\text { problems well. }\end{array}$ & 1 & 2 & 3 & 4 & 5 \\
\hline 7 & I believe that I can be more active. & 1 & 2 & 3 & 4 & 5 \\
\hline 8 & $\begin{array}{l}\text { I am sure that I will do what is best to } \\
\text { keep myself healthy. }\end{array}$ & 1 & 2 & 3 & 4 & 5 \\
\hline 9 & $\begin{array}{l}\text { I am sure that I can spend less time } \\
\text { watching TV. }\end{array}$ & 1 & 2 & 3 & 4 & 5 \\
\hline 10 & $\begin{array}{l}\text { I know that I can make healthy snack } \\
\text { choices regularly. }\end{array}$ & 1 & 2 & 3 & 4 & 5 \\
\hline 11 & $\begin{array}{l}\text { I can deal with pressure from other } \\
\text { people in positive ways. }\end{array}$ & 1 & 2 & 3 & 4 & 5 \\
\hline 12 & $\begin{array}{l}\text { I know what to do when things bother } \\
\text { or upset me. }\end{array}$ & 1 & 2 & 3 & 4 & 5 \\
\hline 13 & $\begin{array}{l}\text { I believe that my parents and family } \\
\text { will help me to reach my goals. }\end{array}$ & 1 & 2 & 3 & 4 & 5 \\
\hline 14 & $\begin{array}{l}\text { I am sure that I will feel better about } \\
\text { myself if I exercise regularly. }\end{array}$ & 1 & 2 & 3 & 4 & 5 \\
\hline 15 & I believe that being active is fun. & 1 & 2 & 3 & 4 & 5 \\
\hline 16 & I am able to talk to my parents/family. & 1 & 2 & 3 & 4 & 5 \\
\hline
\end{tabular}




\section{Appendix C}

Code

\section{Healthy Lifestyle Behavior Scale for Teens}

\section{Pre/Post Test Questions for Teens}

\begin{tabular}{|l|l|l|l|l|l|l|}
\hline & $\begin{array}{l}\text { Please answer the following questions to the best of } \\
\text { your ability. There are no right or wrong answers. }\end{array}$ & $\begin{array}{l}\text { Very } \\
\text { hard to } \\
\text { do }\end{array}$ & $\begin{array}{l}\text { Fairly } \\
\text { hard } \\
\text { to do } \\
\text { heither } \\
\text { nor } \\
\text { easy to } \\
\text { do }\end{array}$ & $\begin{array}{l}\text { Fairly } \\
\text { easy } \\
\text { to do }\end{array}$ & $\begin{array}{l}\text { Very } \\
\text { easy } \\
\text { to do }\end{array}$ \\
\hline 1 & I make healthy food choices & 1 & 2 & 3 & 4 & 5 \\
\hline 2 & I exercise on a regular basis & 1 & 2 & 3 & 4 & 5 \\
\hline 3 & I exercise with my friends/parents. & 1 & 2 & 3 & 4 & 5 \\
\hline 4 & $\begin{array}{l}\text { I limit my television viewing and video game playing } \\
\text { to 2 hours day or less. }\end{array}$ & 1 & 2 & 3 & 4 & 5 \\
\hline 5 & I eat fresh fruit and vegetables for snacks. & 1 & 2 & 3 & 4 & 5 \\
\hline 6 & $\begin{array}{l}\text { I say something positive to my friend/parents every } \\
\text { day. }\end{array}$ & 1 & 2 & 3 & 4 & 5 \\
\hline 7 & I eat less salt and fat in my diet & 1 & 2 & 3 & 4 & 5 \\
\hline 8 & $\begin{array}{l}\text { I drink only two sugared drinks daily (example soda or } \\
\text { fruit juice) }\end{array}$ & 1 & 2 & 3 & 4 & 5 \\
\hline 9 & $\begin{array}{l}\text { I choose water as a beverage in place of a sugared } \\
\text { drink at least once a day. }\end{array}$ & 1 & 2 & 3 & 4 & 5 \\
\hline 10 & I set goal I can accomplish & 1 & 2 & 3 & 4 & 5 \\
\hline 11 & I eat at least three meals a day with my family. & 1 & 2 & 3 & 4 & 5 \\
\hline 12 & I do not add salt to my food. & 1 & 2 & 3 & 4 & 5 \\
\hline 13 & I eat broiled or baked food instead of fried food. & 1 & 2 & 3 & 4 & 5 \\
\hline 14 & I talk about my worries or stress every day. & 1 & 2 & 3 & 4 & 5 \\
\hline 15 & I do what I should do to lead a healthy life & 1 & 2 & 3 & 4 & 5 \\
\hline 16 & $\begin{array}{l}\text { I do healthy things to cope/deal with my worries and } \\
\text { stress. }\end{array}$ & 1 & 2 & 3 & 4 & 5 \\
\hline & & & & & & \\
\hline
\end{tabular}




\section{Appendix D}

Code Number

\section{Nutrition Questions for Teens Pre-Test/Post Test (Circle One)}

\begin{tabular}{|c|c|c|c|c|}
\hline & & True & False & $\begin{array}{c}\text { I } \\
\text { don't } \\
\text { Know } \\
\end{array}$ \\
\hline 1. & $\begin{array}{l}\text { People need to drink } 3 \text { large glasses of milk per day } \\
\text { ( } 8 \text { ounce glass). }\end{array}$ & 0 & 1 & 2 \\
\hline 2. & It is a good idea to have fruit juice at every meal. & 0 & 1 & 2 \\
\hline 3. & Whole milk is healthier than skim milk. & 0 & 1 & 2 \\
\hline 4. & $\begin{array}{l}\text { Ice cream is healthier for you than low fat frozen } \\
\text { Yogurt }\end{array}$ & 0 & 1 & 2 \\
\hline 5. & Pretzels are higher in fat than potato chips. & 0 & 1 & 2 \\
\hline 6. & French fries are a good vegetable choice. & 0 & 1 & 2 \\
\hline 7. & It is better to broil foods than to fry them. & 0 & 1 & 2 \\
\hline 8. & $\begin{array}{l}\text { Eating chicken with skin on it is healthier than eating } \\
\text { chicken without skin. }\end{array}$ & 0 & 1 & 2 \\
\hline 9. & A fruit rollup is a good fruit choice. & 0 & 1 & 2 \\
\hline 10. & It is a good thing to add salt to food. & 0 & 1 & 2 \\
\hline 11. & $\begin{array}{l}\text { Consuming a lot of fruit juice can lead to cavities in } \\
\text { your teeth. }\end{array}$ & 0 & 1 & 2 \\
\hline 12. & White bread has as much fiber in it as wheat bread. & 0 & 1 & 2 \\
\hline 13. & $\begin{array}{l}\text { Soda is just as good of a drink choice as carbonated } \\
\text { Bottled water. }\end{array}$ & 0 & 1 & 3 \\
\hline 14. & $\begin{array}{l}\text { The amount of salty food someone eats can cause } \\
\text { high blood pressure. }\end{array}$ & 0 & 1 & 2 \\
\hline 15. & Fruit Loops are just as healthy as Raisin Bran cereal. & 0 & 1 & 2 \\
\hline 16. & Canned soups have a healthy amount of salt in them & 0 & 1 & 2 \\
\hline 17. & $\begin{array}{l}\text { Dried soups (for example, Ramen noodles) are a } \\
\text { healthy choice for lunch or snack. }\end{array}$ & 0 & 1 & 2 \\
\hline 18. & $\begin{array}{l}\text { Packaged peanut butter crackers are a better snack } \\
\text { than yogurt. }\end{array}$ & 0 & 1 & 2 \\
\hline 19. & $\begin{array}{l}\text { One serving size of meat should be the size of a deck } \\
\text { of cards. }\end{array}$ & 0 & 1 & 2 \\
\hline 20. & $\begin{array}{l}\text { People eat more when they are bored than when they } \\
\text { are busy. }\end{array}$ & 0 & 1 & 2 \\
\hline
\end{tabular}




\section{Appendix E}

Code Number

\section{Test Activity Questions for Teens}

Pre-Test/Post (Circle One)

Directions: Please answer the following questions to the best of your ability.

\begin{tabular}{|l|l|l|l|l|}
\hline & & YES & NO & $\begin{array}{l}\text { Don't } \\
\text { Know }\end{array}$ \\
\hline 1. & Exercise helps to reduce stress & 0 & 1 & 2 \\
\hline 2. & $\begin{array}{l}\text { People who are very active are healthier than people who are } \\
\text { not. }\end{array}$ & 0 & 1 & 2 \\
\hline 3. & Being active can give you more energy. & 0 & 1 & 2 \\
\hline 4. & Being active can lower your blood pressure. & 0 & 1 & 2 \\
\hline 5. & Exercise can help to prevent diabetes. & 0 & 1 & 2 \\
\hline 6. & Regular exercise can make you feel happy. & 0 & 1 & 2 \\
\hline 7. & Running is better for you than walking. & 0 & 1 & 2 \\
\hline 8. & Dancing is exercise. & 0 & 1 & 2 \\
\hline 9. & $\begin{array}{l}\text { Being out of breath and dizzy when you exercise is a sign of a } \\
\text { good workout. }\end{array}$ & 0 & 1 & 2 \\
\hline 10. & $\begin{array}{l}\text { People who exercise 3 or more times each week burn more } \\
\text { calories every day than people who do not. }\end{array}$ & 0 & 1 & 2 \\
\hline 11. & $\begin{array}{l}\text { Children whose parents exercise tend to be more active than } \\
\text { children whose parents do not exercise. }\end{array}$ & 0 & 1 & 2 \\
\hline 12. & $\begin{array}{l}\text { It is good to stretch out and do some slow activities before } \\
\text { exercise. }\end{array}$ & 0 & 1 & 2 \\
\hline
\end{tabular}


Appendix F

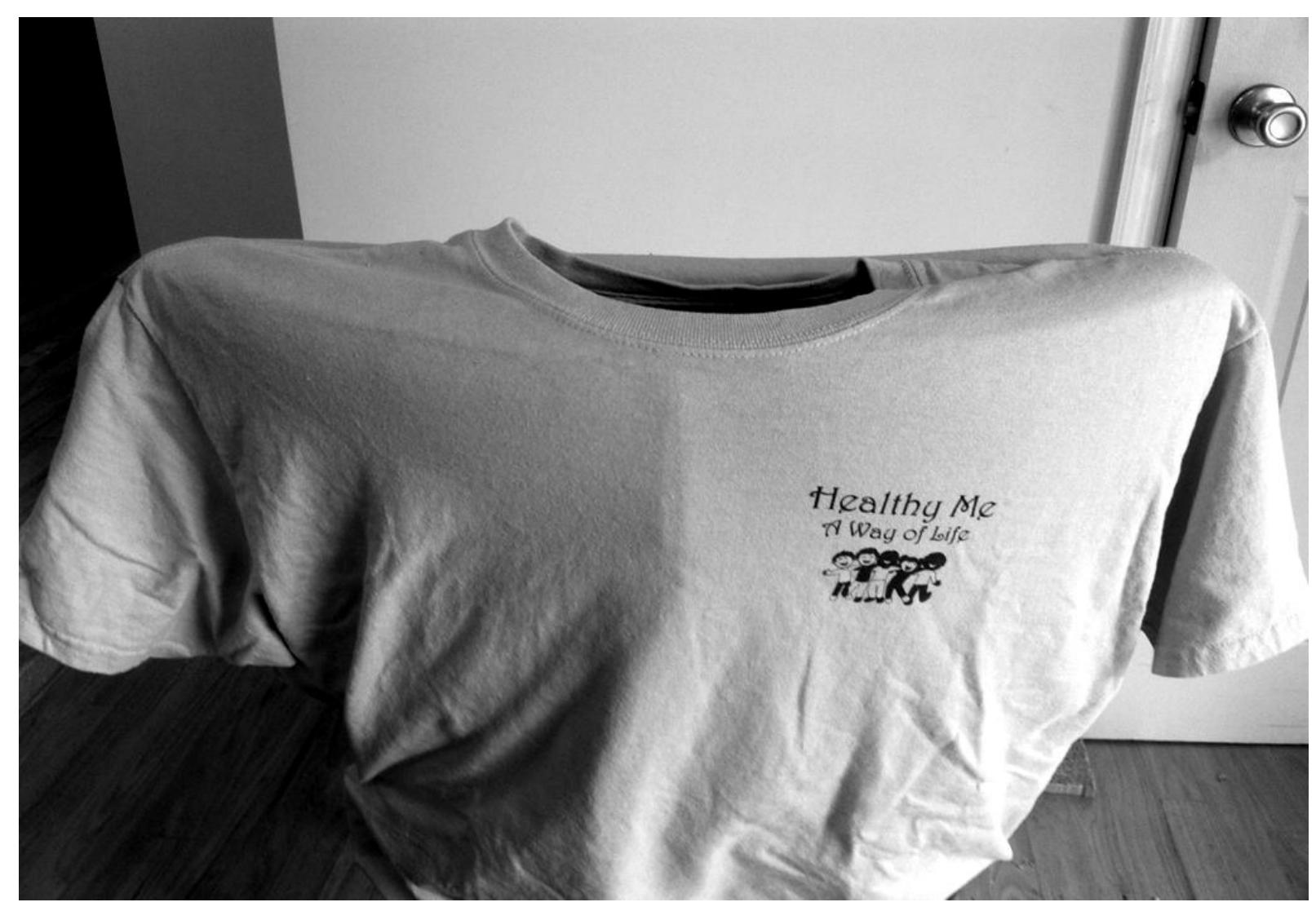


Appendix G

\section{Healthy Cooking in Maryland}
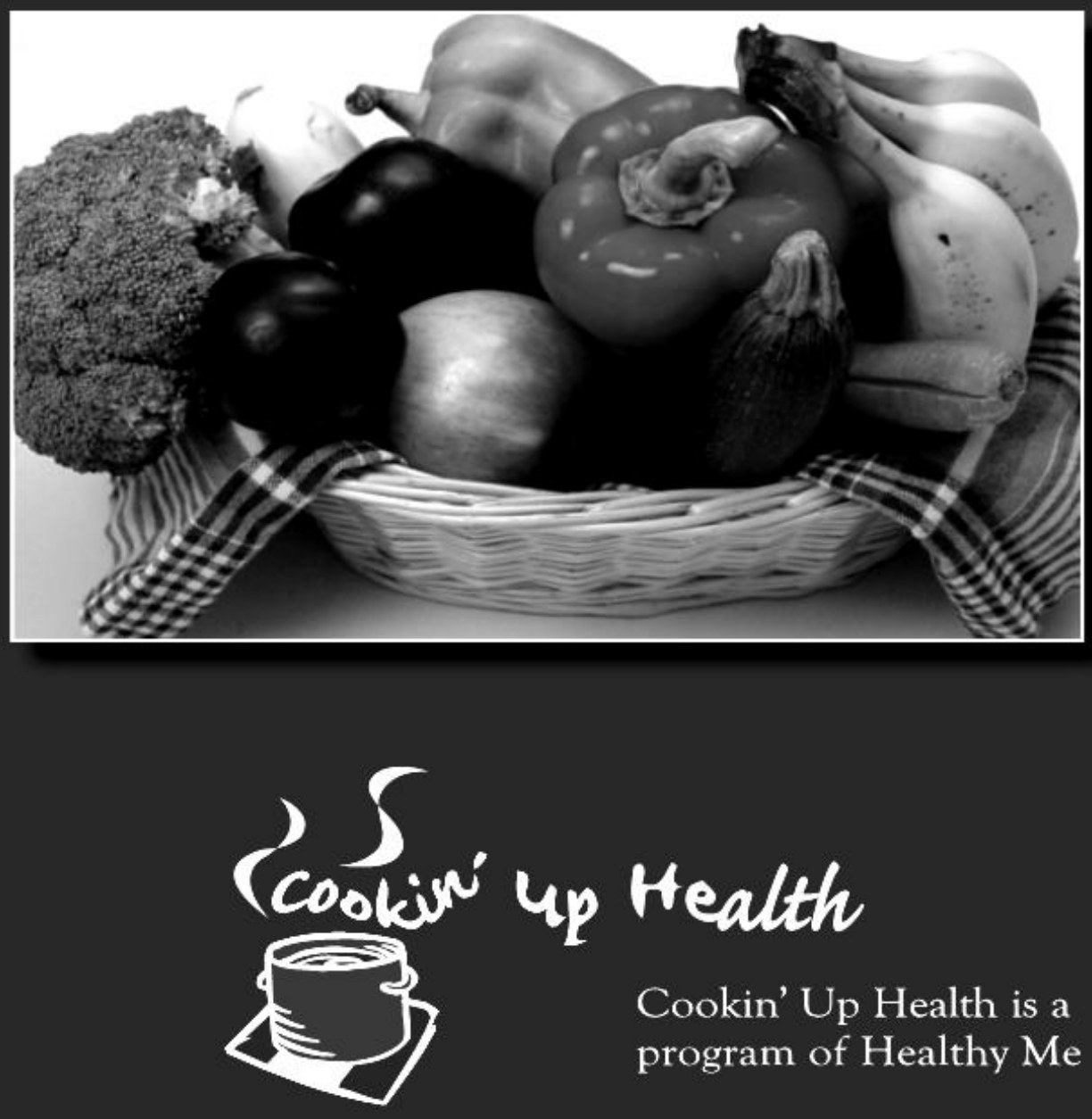


\section{Appendix $\mathbf{H}$}

Budget Table

\begin{tabular}{|l|l|r|l|r|}
\hline Personnel & Budget & $\begin{array}{l}\text { Proposed } \\
\text { Salaries }\end{array}$ & Actual Salary & Difference \\
\hline NP & 0 & & 0 & $0 \%$ \\
\hline Medical Assistant & 0 & 200.00 & $0 \%$ \\
\hline Zumba Teacher & $\$ 200.00$ & 200.00 & & $0 \%$ \\
\hline Yoga Teacher & $\$ 200.00$ & & & $0.0 \%$ \\
\hline & & Proposed & Actual Expense & Difference \\
\hline Operating & Budget & 250.00 & & $0.0 \%$ \\
\hline $\begin{array}{l}\text { Marketing: printing of flyers, } \\
\text { posters }\end{array}$ & $\$ 250.00$ & $8,000.00$ & & $0.0 \%$ \\
\hline Sports equipment & $\$ 8,000.00$ & 500.00 & & $0.0 \%$ \\
\hline Snacks & $\$ 500.00$ & 1550.00 & & $0.0 \%$ \\
\hline $\begin{array}{l}\text { Dinner for parents and } \\
\text { students }\end{array}$ & $\$ 1550.00$ & 600.00 & & $0.0 \%$ \\
\hline T-Shirts for participants & $\$ 600.00$ & 100.00 & & $0.0 \%$ \\
\hline $\begin{array}{l}\text { Invitations/Postage for } \\
\text { Dinners }\end{array}$ & $\$ 100.00$ & $6,00.00$ & & $0.0 \%$ \\
\hline Printing of Cookbooks & $\$ 600.00$ & 500.00 & & \\
\hline COPE/Teen Program & $\$ 500.00$ & & & \\
\hline
\end{tabular}




\section{Appendix I}

2 to 20 years: Boys Stature-for-age and Weight-for-age percentiles
NAME

RECORD \#

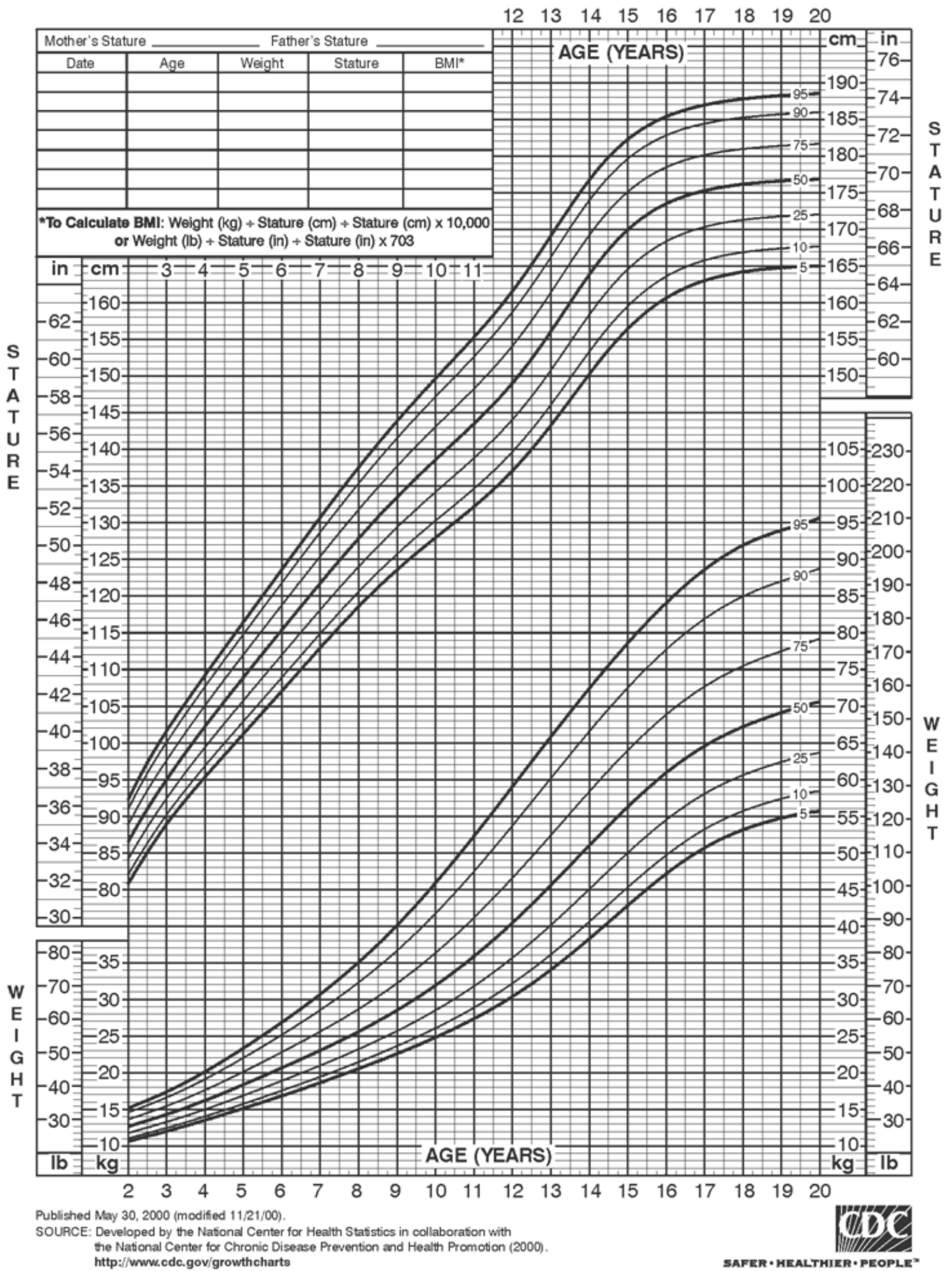




\section{Appendix J}

2 to 20 years: Girls Stature-for-age and Weight-for-age percentiles
NAME

RECORD \#

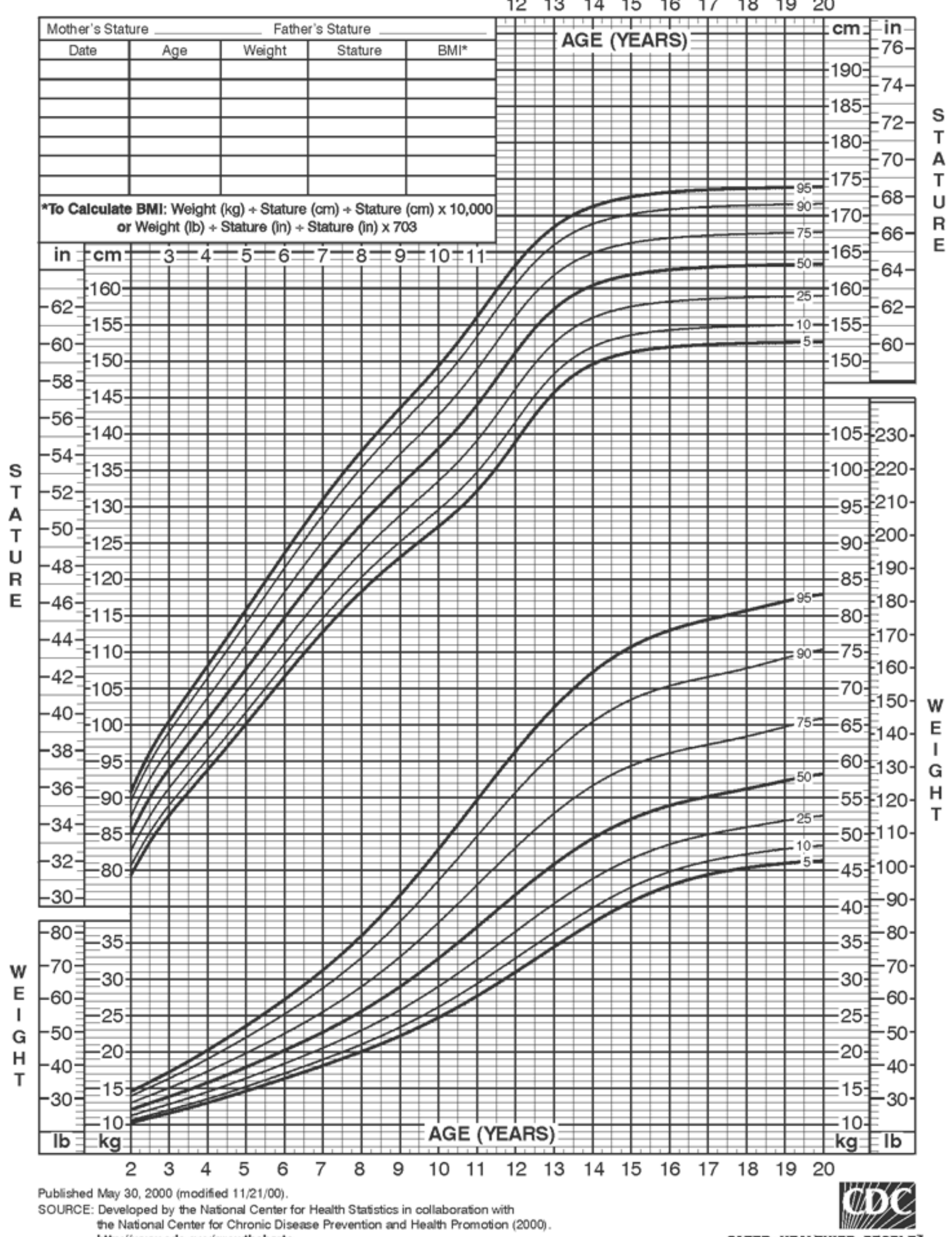

http://unwu.cdc.gov/growthcharts 


\section{Appendix K}

Evidence Table

\begin{tabular}{|c|c|c|c|c|c|c|}
\hline $\begin{array}{l}\text { Author } \\
\text { (Date) }\end{array}$ & $\begin{array}{l}\text { Aim, Research } \\
\text { Question or } \\
\text { Hypothesis }\end{array}$ & $\begin{array}{l}\text { Methodology, } \\
\text { Design, Site, } \\
\text { Sample Size }\end{array}$ & Intervention & $\begin{array}{l}\text { Variables and } \\
\text { Instruments }\end{array}$ & Results & Strengths / Limitations \\
\hline $\begin{array}{l}\text { Black, M } \\
\text { et al. } \\
(2010)\end{array}$ & $\begin{array}{l}\text { "The objective of } \\
\text { this study was to } \\
\text { evaluate a 12- } \\
\text { session } \\
\text { home/community- } \\
\text { based health } \\
\text { promotion/obesity } \\
\text { prevention program } \\
\text { (Challenge!) on } \\
\text { changes in BMI } \\
\text { status, body } \\
\text { composition, } \\
\text { physical activity, } \\
\text { and diet." }\end{array}$ & $\begin{array}{l}\text { RCT } \\
\text { Site: } \\
\text { Urban university } \\
\text { medical center } \\
\text { Home and } \\
\text { community based } \\
\text { health } \\
\text { promotion/obesity } \\
\text { prevention program } \\
\text { (Challenge) on } \\
\text { changes in BMI } \\
\text { Status, body } \\
\text { composition, } \\
\text { physical activity } \\
\text { and diet. } \\
\\
\text { Sample Size } \\
\text { 237 students }\end{array}$ & $\begin{array}{l}\text { Challenge } \\
\text { Program } \\
\text { Home and } \\
\text { Community } \\
\text { Based Health } \\
\text { Promotion and } \\
\text { Obesity } \\
\text { Prevention } \\
\text { Program }\end{array}$ & $\begin{array}{l}\text { Independent } \\
\text { Variable } \\
\text { Challenge Program } \\
\text { Dependent Variable } \\
\text { Change in accretion } \\
\text { of body mass and } \\
\text { body fat } \\
\text { Changes in diet and } \\
\text { physical activity } \\
\text { Instrument } \\
\text { Manualized } 12 \\
\text { Session intervention } \\
\text { based on } \\
\text { Social cognitive } \\
\text { theory } \\
\text { Healthy snacks were } \\
\text { provided and subjects } \\
\text { were engaged in } \\
\text { physical activity with } \\
\text { their mentor. }\end{array}$ & $\begin{array}{l}\text { Retention } 76 \% \text { over } 2 \\
\text { yrs. } \\
\text { Overweight/obese } \\
\text { Status declined } \\
\text { Declined } 5 \% \text { in the } \\
\text { intervention group and } \\
\text { increased } 11 \% \text { in the } \\
\text { control group }\end{array}$ & $\begin{array}{l}\text { Strengths } \\
12 \text { session program } \\
\text { Was followed by an } 11 \text { month } \\
\text { and } 2 \text { year follow up. } \\
\text { Not restricted to overweight or } \\
\text { obese } \\
\text { Home based which would } \\
\text { include } \\
\text { parents/guardians } \\
\text { Manualized intervention } \\
\text { Adapted to culture } \\
\text { Limitations } \\
\text { Relationships with mentors } \\
\text { may vary } \\
\text { Program limited in } \\
\text { generalizability. It is limited to } \\
\text { low income urban blacks. } \\
\text { More intervention adolescents } \\
\text { were overweight/ } \\
\text { obese than in the control group }\end{array}$ \\
\hline
\end{tabular}




\begin{tabular}{|c|c|c|c|c|c|c|}
\hline $\begin{array}{l}\text { Author } \\
\text { (Date) }\end{array}$ & $\begin{array}{l}\text { Aim, Research } \\
\text { Question or } \\
\text { Hypothesis }\end{array}$ & $\begin{array}{l}\text { Methodology, } \\
\text { Design, Site, } \\
\text { Sample Size }\end{array}$ & Intervention & $\begin{array}{l}\text { Variables and } \\
\text { Instruments }\end{array}$ & Results & Strengths / Limitations \\
\hline $\begin{array}{l}\text { Sveinung } \\
\text { et al. } \\
\text { (2010) }\end{array}$ & $\begin{array}{l}\text { To determine if } 5 \\
\text { months of guided } \\
\text { active play in } \\
\text { overweight or obese } \\
\text { children and } \\
\text { adolescents under } \\
\text { multi-disciplinary } \\
\text { management leads } \\
\text { to increased } \\
\text { physical activity in } \\
\text { leisure time, as well } \\
\text { as changes in } \\
\text { aerobic fitness and } \\
\text { body composition. }\end{array}$ & $\begin{array}{l}\text { RCT } \\
\text { Design } \\
\text { Multidisciplinary } \\
\text { management to } \\
\text { provide all aspects } \\
\text { that contribute to wt } \\
\text { loss } \\
\text { Sample Size } \\
60 \text { Obese children } \\
\text { or adolescents } \\
\text { were assigned to } \\
\text { intervention or } \\
\text { control group. }\end{array}$ & $\begin{array}{l}\text { Group received } \\
60 \text { minutes of } \\
\text { guided physical } \\
\text { play/ activity } \\
\text { twice weekly } \\
\text { for five months }\end{array}$ & $\begin{array}{l}\text { Independent } \\
\text { Variable } \\
60 \text { minutes of guided } \\
\text { activity } 2 x \text { weekly } \\
\text { Dependent Variable } \\
\text { Changes in diet } \\
\text { Reduction of Body } \\
\text { Fat and changes in } \\
\text { physical activity }\end{array}$ & $\begin{array}{l}\text { Adjusted Physical } \\
\text { Activity } \\
\text { Levels increased from } \\
\text { baseline } \\
\text { (P-0.4). } \\
\\
\text { Percentage of body fat } \\
\text { decreased by } \\
1.8 \%(p-0.04)\end{array}$ & $\begin{array}{l}\text { Strengths } \\
\text { Objective measurements of } \\
\text { physical activity and body } \\
\text { composition in a multi- } \\
\text { disciplinary management } \\
\text { program with close follow-up } \\
\text { of subjects } \\
\text { Accelerometers' use gives } \\
\text { reliable measures of physical } \\
\text { activity(pedometers) } \\
\text { Weaknesses/ } \\
\text { Limitations } \\
\text { Short duration of study } \\
\text { Lack of adherence to active } \\
\text { play } \\
\text { Cut off point of time needed } \\
\text { vs. adherence to program was } \\
\text { not evaluated. }\end{array}$ \\
\hline $\begin{array}{l}\text { Leite, N. } \\
\text { et al. } \\
\text { (2009) }\end{array}$ & $\begin{array}{l}\text { Objectives: To } \\
\text { analyze the effects } \\
\text { of physical exercise } \\
\text { and nutritional } \\
\text { guidance on body } \\
\text { composition, } \\
\text { physical } \\
\text { fitness, lipid profile } \\
\text { and } \\
\text { insulin resistance }\end{array}$ & $\begin{array}{l}\text { RCT } \\
\text { Site } \\
\text { not identified in } \\
\text { article } \\
\text { Sample Size } \\
\text { Two groups: one } \\
\text { with metabolic } \\
\text { syndrome }(n=29)\end{array}$ & $\begin{array}{l}12 \text { weeks of } \\
\text { physical } \\
\text { education and } \\
\text { two nutritional } \\
\text { guidance } \\
\text { sessions. Each } \\
\text { physical } \\
\text { Education } \\
\text { session } \\
\text { consisted of } 50\end{array}$ & $\begin{array}{l}\text { Independent } \\
\text { Variable } \\
12 \text { weeks of physical } \\
\text { activity and } \\
\text { nutritional education } \\
\text { Dependent Variable } \\
\text { Total body mass }\end{array}$ & $\begin{array}{l}\text { Obese participants } \\
\text { with metabolic } \\
\text { syndrome showed } \\
\text { significant reductions } \\
\text { in total body } \\
\text { mass }(p=0.001), \text { BMI } \\
\text { z-score }(p<0.001), \\
\text { Data showed that } 72 \% \\
\text { of the }\end{array}$ & $\begin{array}{l}\text { Strength } \\
\text { Reduction in risk factors } \\
\text { Matched subjects in each group } \\
\text { Limitations } \\
\text { Lack of control group without } \\
\text { physical exercise or nutritional } \\
\text { guidance } \\
\text { Data must be viewed with }\end{array}$ \\
\hline
\end{tabular}




\begin{tabular}{|c|c|c|c|c|c|c|}
\hline $\begin{array}{l}\text { Author } \\
\text { (Date) }\end{array}$ & $\begin{array}{l}\text { Aim, Research } \\
\text { Question or } \\
\text { Hypothesis }\end{array}$ & $\begin{array}{l}\text { Methodology, } \\
\text { Design, Site, } \\
\text { Sample Size }\end{array}$ & Intervention & $\begin{array}{l}\text { Variables and } \\
\text { Instruments }\end{array}$ & Results & Strengths / Limitations \\
\hline & $\begin{array}{l}\text { among obese } \\
\text { adolescents with and } \\
\text { without metabolic } \\
\text { syndrome }\end{array}$ & $\begin{array}{l}\text { and one without } \\
\text { metabolic } \\
\text { syndrome }(n=35) \text {. }\end{array}$ & $\begin{array}{l}\text { min indoor } \\
\text { cycling, } 50 \text { min } \\
\text { of } \\
\text { walking/running } \\
\text { and } 20 \text { min of } \\
\text { stretching, three } \\
\text { times a week. }\end{array}$ & & $\begin{array}{l}\text { adolescents who had } \\
\text { been diagnosed as } \\
\text { presenting with } \\
\text { metabolic syndrome } \\
\text { resolved this issue }\end{array}$ & $\begin{array}{l}\text { caution because the criteria } \\
\text { applied for diagnosing } \\
\text { metabolic syndrome was } \\
\text { derived from an adult } \\
\text { population. } \\
\text { Data still needs to be } \\
\text { experimentally confirmed for } \\
\text { adolescents }\end{array}$ \\
\hline $\begin{array}{l}\text { Adamo } \\
(2010)\end{array}$ & $\begin{array}{l}\text { The purpose of this } \\
\text { study was to } \\
\text { examine the efficacy } \\
\text { of interactive video } \\
\text { game stationary } \\
\text { cycling } \\
\text { (Game Bike) } \\
\text { in comparison with } \\
\text { stationary cycling to } \\
\text { music on adherence, } \\
\text { energy expenditure } \\
\text { measures, sub } \\
\text { maximal aerobic } \\
\text { fitness, } \\
\text { body composition, } \\
\text { and cardiovascular } \\
\text { disease risk markers } \\
\text { in overweight and } \\
\text { obese adolescents }\end{array}$ & $\begin{array}{l}\text { RCT } \\
\text { Thirty overweight } \\
\text { (with at least } 1 \\
\text { metabolic } \\
\text { complication) or } \\
\text { obese adolescents } \\
\text { aged } 12-17 \text { years } \\
\text { were } \\
\text { stratified by gender } \\
\text { and randomized to } \\
\text { one of two } \\
\text { interventions. }\end{array}$ & $\begin{array}{l}\text { Video game or } \\
\text { music } \\
\text { conditioning, } \\
\text { with } 60 \text { minute } \\
\text { sessions during } \\
\text { the } 10 \text {-week } \\
\text { trial while } \\
\text { participants } \\
\text { were pedaling. } \\
\text { (Bike has games } \\
\text { attached and is } \\
\text { very expensive) }\end{array}$ & $\begin{array}{l}\text { Independent } \\
\text { Variables } \\
\text { Video games or } \\
\text { music while } \\
\text { Conditioning } \\
\text { Dependent Variable } \\
\text { Cardio fitness and } \\
\text { weight loss }\end{array}$ & $\begin{array}{l}\text { Ratio of peak HR to } \\
\text { wattage (workload) } \\
\text { before and after the } \\
\text { exercise intervention } \\
\text { were compared } \\
\text { using a Wilcoxon's } \\
\text { signed rank test. The } \\
\text { level } \\
\text { of significance was set } \\
\text { a priori at } p<0.05 \\
\text { Both the music and } \\
\text { video game condition } \\
\text { produced significant } \\
\text { improvements in peak } \\
\text { HR ( } p=0.004) \text { (i.e., } \\
\text { reduction } \\
\text { in peak HR at peak } \\
\text { workload), peak } \\
\text { workload }(p=0.038) \text {, } \\
\text { and time to exhaustion } \\
(p=0.038) .\end{array}$ & $\begin{array}{l}\text { Strengths } \\
\text { First research related to this } \\
\text { topic (expensive equipment } \\
\text { versus less expensive } \\
\text { equipment) } \\
\text { Solely focused on identified } \\
\text { exercise. } \\
\text { Participants told not to change } \\
\text { their diets. } \\
\text { Gives support for using } \\
\text { exercise of adolescent friendly } \\
\text { type to promote cardio fitness } \\
\text { and weight loss in } \\
\text { overweight/obese } \\
\text { Limitations } \\
\text { relatively small sample } \\
\text { Limits generalizability to } \\
\text { overweight or obese } \\
\text { adolescents- may not } \\
\text { apply to normal subjects. } \\
\text { Present study included an equal } \\
\text { ratio of males to females, but } \\
\text { the sample size is too small to }\end{array}$ \\
\hline
\end{tabular}




\begin{tabular}{|c|c|c|c|c|c|c|}
\hline $\begin{array}{l}\text { Author } \\
\text { (Date) }\end{array}$ & $\begin{array}{l}\text { Aim, Research } \\
\text { Question or } \\
\text { Hypothesis }\end{array}$ & $\begin{array}{l}\text { Methodology, } \\
\text { Design, Site, } \\
\text { Sample Size }\end{array}$ & Intervention & $\begin{array}{l}\text { Variables and } \\
\text { Instruments }\end{array}$ & Results & Strengths / Limitations \\
\hline & & & & & & $\begin{array}{l}\text { determine meaningful gender } \\
\text { differences in response to each } \\
\text { intervention. } \\
\text { adolescents }\end{array}$ \\
\hline $\begin{array}{l}\text { Doyle et } \\
\text { al. } \\
\text { (2008) }\end{array}$ & $\begin{array}{l}\text { To evaluate the } \\
\text { effectiveness of a } \\
\text { multisite IT } \\
\text { delivered program } \\
\text { on weight loss and } \\
\text { decrease in eating } \\
\text { disorders in } \\
\text { adolescents. }\end{array}$ & $\begin{array}{l}\text { RCT } \\
80 \text { overweight } \\
\text { students completed } \\
\text { a } 16 \text { week } \\
\text { cognitive-behavior } \\
\text { program or usual } \\
\text { care. }\end{array}$ & $\begin{array}{l}\text { Student Bodies } \\
2 \text { Program }\end{array}$ & $\begin{array}{l}\text { Independent } \\
\text { Variable } \\
\text { Student Bodies } 2 \\
\text { Dependent Variable } \\
\text { Weight loss and } \\
\text { eating disorder } \\
\text { attitudes }\end{array}$ & $\begin{array}{l}\text { "Body mass index } \\
\text { (BMI) } z \text {-scores were } \\
\text { reduced in the SB2 } \\
\text { group compared with } \\
\text { the UC group from } \\
\text { baseline to post- } \\
\text { intervention ( } p=.027 \text {; } \\
\left.\eta_{\mathrm{p}}^{2}=.08\right) \text {." } \\
\text { The SB2 group } \\
\text { maintained this } \\
\text { reduction in BMI } z \text { - } \\
\text { scores at 4-month } \\
\text { follow-up, but } \\
\text { significant differences } \\
\text { were not observed } \\
\text { because of } \\
\text { improvement in the } \\
\text { UC group } \\
\text { The SB2 group } \\
\text { evidenced greater } \\
\text { increases in dietary } \\
\text { restraint post- } \\
\text { intervention }(p=.016) \\
\text { and less improvement } \\
\text { on shape concerns at } \\
\text { follow-up ( } p=.044) \text {; } \\
\text { however these } \\
\text { differences were not } \\
\text { clinically significant. } \\
\text { No other statistically } \\
\text { significant differences } \\
\text { were noted between }\end{array}$ & $\begin{array}{l}\text { Strengths } \\
\text { RCT design using usual care } \\
\text { versus treatment group } \\
\text { Ethnically diverse } \\
\text { Most studies are with white } \\
\text { overweight } \\
\text { adolescents } \\
\text { Limitations } \\
\text { Small sample size } \\
\text { Lack of long term follow-up. } \\
\text { Adolescents lack of comfort } \\
\text { with internet or lack of access } \\
\text { to internet. }\end{array}$ \\
\hline
\end{tabular}




\begin{tabular}{|c|c|c|c|c|c|c|}
\hline $\begin{array}{l}\text { Author } \\
\text { (Date) }\end{array}$ & $\begin{array}{l}\text { Aim, Research } \\
\text { Question or } \\
\text { Hypothesis }\end{array}$ & $\begin{array}{l}\text { Methodology, } \\
\text { Design, Site, } \\
\text { Sample Size }\end{array}$ & Intervention & $\begin{array}{l}\text { Variables and } \\
\text { Instruments }\end{array}$ & Results & Strengths / Limitations \\
\hline & & & & & $\begin{array}{l}\text { groups on ED attitudes } \\
\text { or behaviors. The SB2 } \\
\text { participants reported } \\
\text { using healthy eating- } \\
\text { related and physical } \\
\text { activity-related skills } \\
\text { more frequently than } \\
\text { UC participants post- } \\
\text { intervention }(p=.001) \\
\text { and follow-up }(p= \\
.012) .{ }^{2}\end{array}$ & \\
\hline $\begin{array}{l}\text { Cliff, D, } \\
\text { et al. } \\
\text { (2010) }\end{array}$ & $\begin{array}{l}\text { Aim } \\
\text { Systematic Review } \\
\text { of "impact of child } \\
\text { and adolescent } \\
\text { obesity treatment } \\
\text { interventions on } \\
\text { physical activity" }\end{array}$ & $\begin{array}{l}\text { Studies included } \\
\text { RCTs and } \\
\text { controlled trials on } \\
\text { subjects who were } \\
\text { overweight or obese } \\
\text { and were < } 18 \text { years } \\
\text { Studies must report } \\
\text { pre and post } \\
\text { treatment physical } \\
\text { activity. } \\
\text { Assessed by two } \\
\text { independent } \\
\text { researchers for } \\
\text { methodological } \\
\text { quality. } \\
20 \text { studies } \\
\text { examined. }\end{array}$ & $\begin{array}{l}\text { Review of } \\
\text { studies. }\end{array}$ & $\begin{array}{l}\text { Independent } \\
12 \text { or } 24 \text { week } \\
\text { nutritional and } \\
\text { exercise } \\
\text { Program } \\
\text { Dependent: Change in } \\
\text { nutrition, physical } \\
\text { activity and BMI }\end{array}$ & $\begin{array}{l}15 \text { studies had an } \\
\text { increase in one } \\
\text { physical activity } \\
\text { outcome at post-test or } \\
\text { follow-up. } \\
\text { Study quality was } \\
\text { rated as low with three } \\
\text { child studies classified } \\
\text { as high quality } \\
\text { ( } \geq 6 / 10) \text {. Research on } \\
\text { effect of child and } \\
\text { adolescent obesity } \\
\text { treatment trials on } \\
\text { physical activity is } \\
\text { limited in both } \\
\text { quantity and quality. } \\
\text { Study quality was low } \\
\text { in most studies } \\
\text { Small samples } \\
\text { Limited cultural and } \\
\text { economic diversity } \\
\text { Need: } \\
\text { Studies testing } \\
\text { innovative, } \\
\text { theoretically driven }\end{array}$ & $\begin{array}{l}\text { Strengths } \\
\text { Isolated physical activity from } \\
\text { research that intervenes with } \\
\text { both nutrition education and } \\
\text { physical activity } \\
\text { Limitations of review } \\
\text { Small number of research } \\
\text { articles included in this } \\
\text { systematic review. }\end{array}$ \\
\hline
\end{tabular}




\begin{tabular}{|c|c|c|c|c|c|c|}
\hline $\begin{array}{l}\text { Author } \\
\text { (Date) }\end{array}$ & $\begin{array}{l}\text { Aim, Research } \\
\text { Question or } \\
\text { Hypothesis }\end{array}$ & $\begin{array}{l}\text { Methodology, } \\
\text { Design, Site, } \\
\text { Sample Size } \\
\end{array}$ & Intervention & $\begin{array}{l}\text { Variables and } \\
\text { Instruments }\end{array}$ & Results & Strengths / Limitations \\
\hline & & & & & $\begin{array}{l}\text { treatment approaches } \\
\text { Robust methodologies. } \\
\text { Increase generalizable } \\
\text { approaches for } \\
\text { promoting physical } \\
\text { activity participation } \\
\text { among obese youth. }\end{array}$ & \\
\hline $\begin{array}{l}\text { Annesi } \\
\text { JJ, et al } \\
\text { (2010) }\end{array}$ & $\begin{array}{l}\text { Aim is to determine } \\
\text { the effect of two } \\
\text { different durations } \\
\text { on changes in } \\
\text { nutrition, physical } \\
\text { activity, and body } \\
\text { mass index (BMI) } \\
\text { and psychological } \\
\text { predictors of BMI } \\
\text { change in } \\
\text { overweight and } \\
\text { obese adolescents at } \\
\text { risk for type } 2 \\
\text { diabetes. }\end{array}$ & $\begin{array}{l}\text { RCT } \\
\text { Study site } \\
\text { YMCA } \\
\text { Sample } \\
\text { Age } 12 \text { to } 17 \text { years } \\
\text { (14.1 mean), 69\% } \\
\text { female, 31\% male, } \\
90 \% \text { African } \\
\text { American, } 8 \% \\
\text { White, 2\% } \\
\text { Hispanic }\end{array}$ & $\begin{array}{l}\text { Program } \\
\text { providing } \\
\text { nutritional } \\
\text { education and } \\
\text { physical } \\
\text { activity. }\end{array}$ & $\begin{array}{l}\text { Independent } \\
12 \text { or } 24 \text { week } \\
\text { nutritional and } \\
\text { exercise } \\
\text { Program } \\
\text { Dependent } \\
\text { Change in eating } \\
\text { habits, physical } \\
\text { activity and BMI }\end{array}$ & $\begin{array}{l}\text { Test statistic } \\
\text { For BMI } \\
\text { Group } 1 \\
\mathrm{t}[34]=0.46 \mathrm{p}=0.64 \\
\mathrm{D}=0.05 ; 95 \% \mathrm{CI} \\
=0.59 \text { to } 0.37 \\
\text { Group } 2 \\
\mathrm{t}[28]=1.00 ; \mathrm{p}=0.33 \\
\mathrm{~d}=0.19 ; 95 \% \mathrm{CI}=- \\
0.46 \text { to } 0.16\end{array}$ & $\begin{array}{l}\text { Strengths } \\
\text { RTC with comparative design } \\
\text { between two lengths of } \\
\text { interventions. } \\
\text { Applicable to obese } \\
\text { adolescents } \\
\text { YMCA site was strength } \\
\text { because it offers "real world } \\
\text { situation. } \\
\text { Limitations } \\
\text { Changes in BMI may be due to } \\
\text { normative changes } \\
\text { The } 24 \text { week group was given a } \\
\text { goal of } 5 \% \text { wt loss which was } \\
\text { not given to } 12 \text { week group and } \\
\text { may account for better results } \\
\text { All the participants were } \\
\text { African American which limit } \\
\text { its generalizability. } \\
\text { The population studied was } \\
\text { severely obese which may and } \\
\text { may not be as effective in } \\
\text { mildly obese or overweight } \\
\text { individuals }\end{array}$ \\
\hline
\end{tabular}




\begin{tabular}{|c|c|c|c|c|c|c|}
\hline $\begin{array}{l}\text { Author } \\
\text { (Date) }\end{array}$ & $\begin{array}{l}\text { Aim, Research } \\
\text { Question or } \\
\text { Hypothesis }\end{array}$ & $\begin{array}{l}\text { Methodology, } \\
\text { Design, Site, } \\
\text { Sample Size }\end{array}$ & Intervention & $\begin{array}{l}\text { Variables and } \\
\text { Instruments }\end{array}$ & Results & Strengths / Limitations \\
\hline $\begin{array}{l}\text { Bernsten } \\
\text { et al. } \\
\text { (2010) }\end{array}$ & $\begin{array}{l}\text { Question of whether } \\
\text { guided active pl;ay } \\
\text { led to increase } \\
\text { physical activity in } \\
\text { leisure time of } \\
\text { participants and } \\
\text { changes in aerobic } \\
\text { fitness and body } \\
\text { composition. }\end{array}$ & $\begin{array}{l}\text { RCT } \\
\text { Subjects assigned } \\
\text { to guided active } \\
\text { play or to control } \\
\text { group } \\
\mathrm{N}=60 \text { obese } \\
\text { children or } \\
\text { adolescents }\end{array}$ & $\begin{array}{l}\text { Guided active } \\
\text { play by multi- } \\
\text { disciplinary } \\
\text { management. }\end{array}$ & $\begin{array}{l}\text { Independent } \\
\text { Program of guided } \\
\text { active play } \\
\text { Dependent variable } \\
\text { Variable was level of } \\
\text { physical activity or } \\
\text { subjects }\end{array}$ & $\begin{array}{l}\text { Adjusted physical } \\
\text { activity levels to } \\
(\mathrm{P}=0.4) \text { (not } \\
\text { significant) } \\
\\
\text { body fat decreased by } \\
1.8 \%(\mathrm{p}=0.04) .\end{array}$ & $\begin{array}{l}\text { Strengths of the study } \\
\text { included objective } \\
\text { measurements of physical } \\
\text { activity } \\
\text { Using accelerometers. } \\
\text { Limitations } \\
\text { Short duration of the program } \\
\text { Lack of adherence to active } \\
\text { play by students. }\end{array}$ \\
\hline $\begin{array}{l}\text { Tse, and } \\
\text { Yuen } \\
\text { (2009) }\end{array}$ & $\begin{array}{l}\text { Health education } \\
\text { would have a } \\
\text { positive effect on } \\
\text { diet and physical } \\
\text { activity }\end{array}$ & $\begin{array}{l}\text { No design } \\
\mathrm{N}=203 \\
\text { Reported as } \\
\text { enhanced } \\
\text { educations program } \\
\text { on nutrition and } \\
\text { physical activity } \\
\text { No control group } \\
\\
\text { Total school } \\
\text { population } \\
\mathrm{n}=203\end{array}$ & $\begin{array}{l}\text { A six month } \\
\text { health education } \\
\text { program }\end{array}$ & $\begin{array}{l}\text { Independent } \\
\text { Variable } \\
\text { Health education } \\
\text { program } \\
\text { Dependent Variable } \\
\text { knowledge of } \\
\text { nutrition and physical } \\
\text { activity } \\
\text { Healthier eating and } \\
\text { increased physical } \\
\text { activity }\end{array}$ & $\begin{array}{l}\text { Marked gains of } \\
\text { knowledge upon the } \\
\text { completion of the } \\
\text { program. } \\
\text { Positive gains in the } \\
\text { diets and activity } \\
\text { levels of the students. } \\
\text { Gains maintained at } 3 \\
\text { month follow up }\end{array}$ & $\begin{array}{l}\text { Strength } \\
\text { Positive gains maintained at } \\
\text { follow up } \\
\text { Limitations } \\
\text { lack of autonomy in } \\
\text { participation } \\
\text { No control group }\end{array}$ \\
\hline $\begin{array}{l}\text { Melnyk } \\
\text { et al. } \\
\text { (2007) }\end{array}$ & $\begin{array}{l}\text { Aim of the research } \\
\text { was to determine the } \\
\text { feasibility of } \\
\text { implementing the } \\
\text { COPE (Creating } \\
\text { Opportunities for } \\
\text { Personal } \\
\text { Empowerment) } \\
\text { Healthy Teens } \\
\text { Program and then to } \\
\text { refine the program }\end{array}$ & $\begin{array}{l}\text { RCT } \\
\text { Pilot program } \\
\mathrm{n}=11 \text { in urban trial } \\
\text { and } \mathrm{n}=13 \text { in } \\
\text { suburban area }\end{array}$ & $\begin{array}{l}\text { COPE/ } \\
\text { TEEN } \\
\text { PROGRAM }\end{array}$ & $\begin{array}{l}\text { Independent } \\
\text { Variable } \\
\text { COPE/TEEN } \\
\text { Dependent Variable } \\
\text { Weight loss and } \\
\text { decrease in BMI }\end{array}$ & $\begin{array}{l}\text { Aggregate weight loss } \\
\text { of } 32 \mathrm{lbs} \text { in the } \\
\text { intervention group } \\
\text { as compared to } 11 \\
\text { pounds for the control } \\
\text { group }\end{array}$ & $\begin{array}{l}\text { Strengths } \\
\text { Positive outcome in wt loss and } \\
\text { positive impression by the } \\
\text { participants in the program } \\
\text { Limitations } \\
\text { Program was after school } \\
\text { Limited number of participants } \\
\text { completed the program }\end{array}$ \\
\hline
\end{tabular}




\begin{tabular}{|c|c|c|c|c|c|c|}
\hline $\begin{array}{l}\text { Author } \\
\text { (Date) }\end{array}$ & $\begin{array}{l}\text { Aim, Research } \\
\text { Question or } \\
\text { Hypothesis }\end{array}$ & $\begin{array}{l}\text { Methodology, } \\
\text { Design, Site, } \\
\text { Sample Size }\end{array}$ & Intervention & $\begin{array}{l}\text { Variables and } \\
\text { Instruments }\end{array}$ & Results & Strengths / Limitations \\
\hline $\begin{array}{l}\text { Tse, M., } \\
\text { \& Yuen, } \\
\text { D. (2009) }\end{array}$ & $\begin{array}{l}\text { This study aims to } \\
\text { use a health } \\
\text { nutrition education } \\
\text { program as an } \\
\text { intervention to } \\
\text { mediate nutrition } \\
\text { behavior changes, } \\
\text { including increasing } \\
\text { nutritional } \\
\text { knowledge and } \\
\text { forming positive } \\
\text { behavioral } \\
\text { interventions to } \\
\text { improve the diet and } \\
\text { physical activity. }\end{array}$ & & & & & $\begin{array}{l}\text { Strengths } \\
\text { Tailor made talk providing } \\
\text { nutritional information and } \\
\text { exercise advice } \\
\text { FU conducted after three } \\
\text { months after } 2^{\text {nd }} \text { phase to assess } \\
\text { changes in dietary style and } \\
\text { lifestyle changes } \\
\text { Questionnaire used had good } \\
\text { content validity } 0.804 \text { and test } \\
\text { retest reliability was r }=0.861 \\
\text { Limitations } \\
\text { Permission only from } \\
\text { headmaster and parents not } \\
\text { from participants. This may be } \\
\text { explained by the culture or it } \\
\text { may be a confounding one }\end{array}$ \\
\hline
\end{tabular}

